4

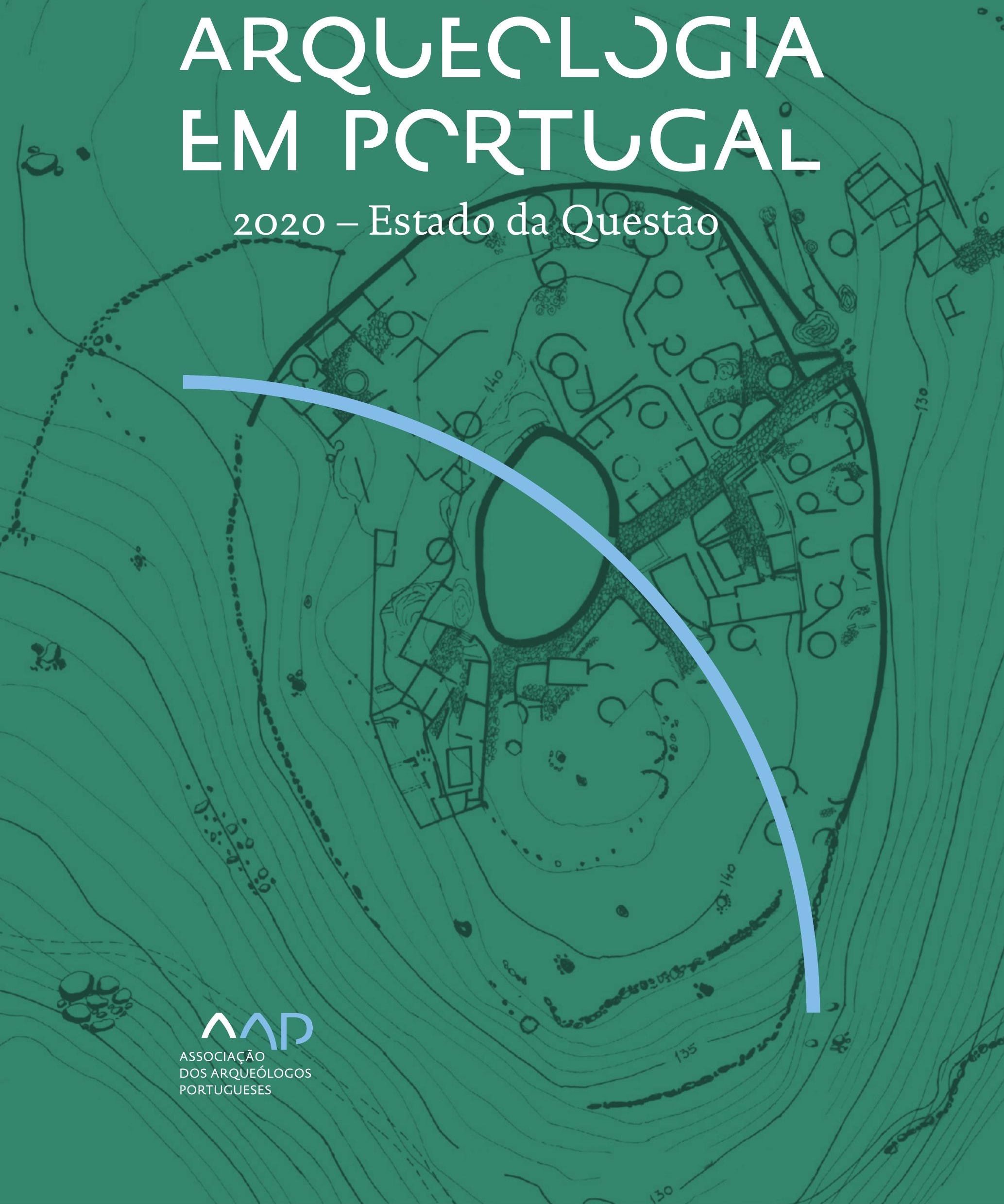


Coordenação editorial: José Morais Arnaud, César Neves e Andrea Martins Design gráfico: Flatland Design

AAP - ISBN: 978-972-9451-89-8

CITCEM - ISBN: 978-989-8970-25-1

Associação dos Arqueólogos Portugueses e CITCEM

Lisboa, 2020

O conteúdo dos artigos é da inteira responsabilidade dos autores. Sendo assim a Associação dos Arqueólogos Portugueses declina qualquer responsabilidade por eventuais equívocos ou questões de ordem ética e legal.

Desenho de capa:

Planta do castro de Monte Mozinho (Museu Municipal de Penafiel).

\section{$\hat{\wedge} \mathrm{P}$}

DOS ARQUEÓLOGOS PORTUGUESES

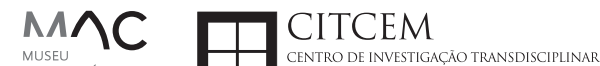
MUSEU
ARQUELLÓGICO
DO CARMO
U.PORTO

FLUP FACULDADE DE LETRAS
UNIVERSIDADE DO PORTO

Apoio

EC para a Ciência 


\section{Índice}

15 Prefácio

José Morais Arnaud

\section{Historiografia e Teoria}

17 Território, comunidade, memória e emoção: a contribuição da história da arqueologia (algumas primeiras e breves reflexões)

Ana Cristina Martins

25 Como descolonizar a arqueologia portuguesa?

Rui Gomes Coelho

41 Arqueologia e Modernidade: uma revisitação pessoal e breve de alguns aspetos da obra homónima de Julian Thomas de 2004

Vítor Oliveira Jorge

57 Dados para a História das Mulheres na Arqueologia portuguesa, dos finais do século XIX aos inícios do século XX: números, nomes e tabelas

Filipa Dimas / Mariana Diniz

73 Retractos da arqueologia portuguesa na imprensa: (in)visibilidades no feminino

Catarina Costeira / Elsa Luís

85 Arqueologia e Arqueólogos no Norte de Portugal Jacinta Bugalhão

101 Vieira Guimarães (1864-1939) e a arqueologia em Tomar: uma abordagem sobre o território e as gentes

João Amendoeira Peixoto / Ana Cristina Martins

115 Os memoráveis? A arqueologia algarvia na imprensa nacional e regional na presente centúria (2001-2019): características, visões do(s) passado(s) e a arqueologia

enquanto marca

Frederico Agosto / João Silva

129 A Evolução da Arqueologia Urbana e a Valorização Patrimonial no Barlavento Algarvio: Os casos de Portimão e Silves

Artur Mateus / Diogo Varandas / Rafael Boavida

\section{Gestão, Valorização e Salvaguarda do Património}

145 O Caderno Reivindicativo e as condições de trabalho em Arqueologia Miguel Rocha / Liliana Matias Carvalho / Regis Barbosa / Mauro Correia / Sara Simões / Jacinta Bugalhão / Sara Brito / Liliana Veríssimo Carvalho / Richard Peace / Pedro Peça / Cézer Santos

155 Os Estudos de Impacte Patrimonial como elemento para uma estratégia sustentável de minimização de impactes no âmbito de reconversões agrícolas Tiago do Pereiro

165 Salvaguarda de Património arqueológico em operações florestais: gestão e sensibilização Filipa Bragança / Gertrudes Zambujo / Sandra Lourenço / Belém Paiva / Carlos Banha / Frederico Tatá Regala / Helena Moura / Jacinta Bugalhão / João Marques / José Correia / Pedro Faria / Samuel Melro

179 Os valores do Património: uma investigação sobre os Sítios Pré-históricos de Arte Rupestre do Vale do Rio Côa e de Siega Verde José Paulo Francisco 
189 Conjugando recursos arqueológicos e naturais para potenciar as visitas ao Geoparque Litoral de Viana do Castelo (Noroeste de Portugal)

Hugo A. Sampaio / Ana M.S. Bettencourt / Susana Marinho / Ricardo Carvalhido

203 Áreas de Potencial Arqueológico na Região do Médio Tejo: Modelo Espacial Preditivo Rita Ferreira Anastácio / Ana Filipa Martins / Luiz Oosterbeek

223 Património Arqueológico e Gestão Territorial: O contributo da Arqueologia para a revisão do PDM de Avis

Ana Cristina Ribeiro

237 A coleção arqueológica do extinto Museu Municipal do Porto - Origens, Percursos e Estudos

Sónia Couto

251 Valpaços - uma nova carta arqueológica

Pedro Pereira / Maria de Fátima Casares Machado

263 Arqueologia na Cidade de Peniche

Adriano Constantino / Luís Rendeiro

273 Arqueologia Urbana: a cidade de Lagos como caso de Estudo Cátia Neto

285 Estratégias de promoção do património cultural subaquático nos Açores. O caso da ilha do Faial

José Luís Neto / José Bettencourt / Luís Borges / Pedro Parreira

297 Carta Arqueológica da Cidade Velha: Uma primeira abordagem

Jaylson Monteiro / Nireide Tavares / Sara da Veiga / Claudino Ramos / Edson Brito /

Carlos Carvalho / Francisco Moreira / Adalberto Tavares

311 Antropologia Virtual: novas metodologias para a análise morfológica e funcional Ricardo Miguel Godinho / Célia Gonçalves

\section{Didáctica da Arqueologia}

327 Como os projetos de Arqueologia podem contribuir para uma comunidade culturalmente mais consciente Alexandra Figueiredo / Claúdio Monteiro / Adolfo Silveira / Ricardo Lopes

337 Educação Patrimonial - Um cidadão esclarecido é um cidadão ativo! Ana Paula Almeida

351 A aproximação da Arqueologia à sala de aula: um caso de estudo no $3^{\circ}$ ciclo do Ensino Básico Luís Serrão Gil

363 Arqueologia 3.o - Pensar e comunicar a Arqueologia para um futuro sustentável Mónica Rolo

377 “Conversa de Arqueólogos" - Divulgar a Arqueologia em tempos de Pandemia Diogo Teixeira Dias

389 Escola Profissional de Arqueologia: desafios e oportunidades Susana Nunes / Dulcineia Pinto / Júlia Silva / Ana Mascarenhas

399 Os Museus de Arqueologia e os Jovens: a oferta educativa para o público adolescente Beatriz Correia Barata / Leonor Medeiros

411 O museu universitário como mediador entre a ciência e a sociedade: o exemplo da secção de arqueologia no Museu de História Natural e da Ciência da Universidade do Porto (MHNC-UP)

Rita Gaspar 
421 Museu de Lanifícios: Real Fábrica de Panos. Atividades no âmbito da Arqueologia Beatriz Correia Barata / Rita Salvado

427 Arqueologia Pública e o caso da localidade da Mata (Torres Novas) Cláudia Manso / Ana Rita Ferreira / Cristiana Ferreira / Vanessa Cardoso Antunes

431 Do sítio arqueológico ao museu: um percurso (também) didático Lídia Fernandes

447 Estão todos convidados para a Festa! E para dançar também... O projecto do Serviço Educativo do Museu Arqueológico do Carmo na $5^{\underline{a}}$ Edição da Festa da Arqueologia Rita Pires dos Santos

459 O “Clã de Carenque”, um projeto didático de arqueologia Eduardo Gonzalez Rocha

469 Mediação cultural: peixe que puxa carroça nas Ruínas Romanas de Troia Inês Vaz Pinto / Ana Patrícia Magalhães / Patrícia Brum / Filipa Santos

481 Didática Arqueológica, experiências do Projeto Mértola Vila Museu Maria de Fátima Palma / Clara Rodrigues / Susana Gómez / Lígia Rafael

\section{Arte Rupestre}

497 Os inventários de arte rupestre em Portugal Mila Simões de Abreu

513 O projeto FIRST-ART - conservação, documentação e gestão das primeiras manifestações de arte rupestre no Sudoeste da Península Ibérica: as grutas do Escoural e Maltravieso Sara Garcês / Hipólito Collado / José Julio García Arranz / Luiz Oosterbeek / António Carlos Silva / Pierluigi Rosina / Hugo Gomes / Anabela Borralheiro Pereira / George Nash / Esmeralda Gomes / Nelson Almeida / Carlos Carpetudo

523 Trabalhos de documentação de arte paleolítica realizados no âmbito do projeto PalæoCôa André Tomás Santos / António Fernando Barbosa / Luís Luís / Marcelo Silvestre / Thierry Aubry

537 Imagens fantasmagóricas, silhuetas elusivas: as figuras humanas na arte do Paleolítico Superior da região do Côa Mário Reis

$55^{1}$ Os motivos zoomórficos representados nas placas de tear de Vila Nova de São Pedro (Azambuja, Portugal) Andrea Martins / César Neves / José M. Arnaud / Mariana Diniz

571 Arte Rupestre do Monte de Góios (Lanhelas, Caminha). Síntese dos resultados dos trabalhos efectuados em 2007-2009 Mário Varela Gomes

599 Gravuras rupestres de barquiformes no Monte de S. Romão, Guimarães, Noroeste de Portugal Daniela Cardoso

613 Círculos segmentados gravados na Bacia do Rio Lima (Noroeste de Portugal): contributos para o seu estudo Diogo Marinho / Ana M.S. Bettencourt / Hugo Aluai Sampaio

631 Equídeos gravados no curso inferior do Rio Mouro, Monção (NW Portugal). Análise preliminar Coutinho, L.M. / Bettencourt, A.M.S / Sampaio, Hugo A.S

645 Paletas na Arte Rupestre do Noroeste de Portugal. Inventário preliminar Bruna Sousa Afonso / Ana M. S. Bettencourt / Hugo A. Sampaio 


\section{Pré-História}

661 O projeto Miño/Minho: balanço de quatro anos de trabalhos arqueológicos Sérgio Monteiro-Rodrigues / João Pedro Cunha-Ribeiro / Eduardo Méndez-Quintas / Carlos Ferreira / Pedro Xavier / José Meireles / Alberto Gomes / Manuel Santonja / Alfredo Pérez-González

677 A ocupação paleolítica da margem esquerda do Baixo Minho: a indústria lítica do sítio de Pedreiras 2 (Monção, Portugal) e a sua integração no contexto regional Carlos Ferreira / João Pedro Cunha-Ribeiro / Sérgio Monteiro-Rodrigues / Eduardo Méndez-Quintas / Pedro Xavier / José Meireles / Alberto Gomes / Manuel Santonja / Alfredo Pérez-González

693 O sítio acheulense do Plistocénico médio da Gruta da Aroeira Joan Daura / Montserrat Sanz / Filipa Rodrigues / Pedro Souto / João Zilhão

703 As sociedades neandertais no Barlavento algarvio: modelos preditivos com recurso aos SIG

Daniela Maio

715 A utilização de quartzo durante o Paleolítico Superior no território dos vales dos rios Vouga e Côa

Cristina Gameiro / Thierry Aubry / Bárbara Costa / Sérgio Gomes / Luís Luís / Carmen Manzano / André Tomás Santos

733 Uma perspetiva diacrónica da ocupação do concheiro do Cabeço da Amoreira (Muge, Portugal) a partir da tecnologia lítica Joana Belmiro / João Cascalheira / Célia Gonçalves

745 Novos dados sobre a Pré-história Antiga no concelho de Palmela. A intervenção arqueológica no sítio do Poceirão I

Michelle Teixeira Santos

757 Problemas em torno de Datas Absolutas Pré-Históricas no Norte do Alentejo Jorge de Oliveira

771 Povoamento pré-histórico nas áreas montanhosas do NO de Portugal: o Abrigo 1 de Vale de Cerdeira Pedro Xavier / José Meireles / Carlos Alves

783 Apreciação do povoamento do Neolítico Inicial na Baixa Bacia do Douro. A Lavra I (Serra da Aboboreira) como caso de estudo Maria de Jesus Sanches

797 O Processo de Neolitização na Plataforma do Mondego: os dados do Sector C do Outeiro dos Castelos de Beijós (Carregal do Sal)

João Carlos de Senna-Martinez / José Manuel Quintã Ventura / Andreia Carvalho / Cíntia Maurício

823 Novos trabalhos na Lapa da Bugalheira (Almonda, Torres Novas) Filipa Rodrigues / Pedro Souto / Artur Ferreira / Alexandre Varanda / Luís Gomes / Helena Gomes / João Zilhão

837 A pedra polida e afeiçoada do sítio do Neolítico médio da Moita do Ourives (Benavente, Portugal)

César Neves

857 Casal do Outeiro (Encarnação, Mafra): novos contributos para o conhecimento do povoamento do Neolítico final na Península de Lisboa.

Cátia Delicado / Carlos Maneira e Costa / Marta Miranda / Ana Catarina Sousa

873 Stresse infantil, morbilidade e mortalidade no sítio arqueológico do Neolítico Final/ Calcolítico ( $4^{\circ}$ e $3^{\circ}$ milénio a.C.) do Monte do Carrascal 2 (Ferreira do Alentejo, Beja) Liliana Matias de Carvalho / Sofia N. Wasterlain 
885 Come together: O Conjunto Megalítico das Motas (Monção, Viana do Castelo) e as expressões Campaniformes do Alto Minho Ana Catarina Basílio / Rui Ramos

899 Trabalhos arqueológicos no sítio Calcolítico da Pedreira do Poio Carla Magalhães / João Muralha / Mário Reis / António Batarda Fernandes

913 O sítio arqueológico de Castanheiro do Vento. Da arquitectura do sítio à arquitectura de um território João Muralha Cardoso

925 Estudo zooarqueológico das faunas do Calcolítico final de Vila Nova de São Pedro (Azambuja, Portugal): Campanhas de 2017 e 2018 Cleia Detry / Ana Catarina Francisco / Mariana Diniz / Andrea Martins / César Neves / José Morais Arnaud

943 As faunas depositadas no Museu Arqueológico do Carmo provenientes de Vila Nova de São Pedro (Azambuja): as campanhas de 1937 a 1967 Ana Catarina Francisco / Cleia Detry / César Neves / Andrea Martins / Mariana Diniz / José Morais Arnaud

959 Análise funcional de material lítico em sílex do castro de Vila Nova de S. Pedro (Azambuja, Portugal): uma primeira abordagem Rafael Lima

971 O recinto da Folha do Ouro 1 (Serpa) no contexto dos recintos de fossos calcolíticos alentejanos

António Carlos Valera / Tiago do Pereiro / Pedro Valério / António M. Monge Soares

\section{Proto-História}

987 Produção de sal marinho na Idade do Bronze do noroeste Português. Alguns dados para uma reflexão

Ana M. S. Bettencourt / Sara Luz / Nuno Oliveira / Pedro P. Simões / Maria Isabel C. Alves / Emílio Abad-Vidal

1001 A estátua-menir do Pedrão ou de São Bartolomeu do Mar (Esposende, noroeste de Portugal) no contexto arqueológico da fachada costeira de entre os rios Neiva e Cávado Ana M. S. Bettencourt / Manuel Santos-Estévez / Pedro Pimenta Simões / Luís Gonçalves

1015 O Castro do Muro (Vandoma/Baltar, Paredes) - notas para uma biografia de ocupação da Idade do Bronze à Idade Média

Maria Antónia D. Silva / Ana M. S. Bettencourt / António Manuel S. P. Silva / Natália Félix

1031 Do Bronze Final à Idade Média - continuidades e hiatos na ocupação de Povoados em Oliveira de Azeméis João Tiago Tavares / Adriaan de Man

1041 As faunas do final da Idade do Bronze no Sul de Portugal: leituras desde o Outeiro do Circo (Beja)

Nelson J. Almeida / Íris Dias / Cleia Detry / Eduardo Porfírio / Miguel Serra

1055 A Espada do Monte das Oliveiras (Serpa) - uma arma do Bronze Pleno do Sudoeste Rui M. G. Monge Soares / Pedro Valério / Mariana Nabais / António M. Monge Soares

1065 São Julião da Branca (Albergaria-a-Velha) - Investigação e valorização de um povoado do Bronze Final

António Manuel S. P. Silva / Paulo A. P. Lemos / Sara Almeida e Silva / Edite Martins de Sá

1083 Do castro de S. João ao Mosteiro de Santa Clara: notícia de uma intervenção arqueológica, em Vila do Conde Rui Pinheiro 
1095 O castro de Ovil (Espinho), um quarto de século de investigação - resultados e questões em aberto

Jorge Fernando Salvador / António Manuel S. P. Silva

1111 O Castro de Salreu (Estarreja), um povoado proto-histórico no litoral do Entre Douro e Vouga

Sara Almeida e Silva / António Manuel S. P. Silva / Paulo A. P. Lemos / Edite Martins de Sá

1127 Castro de Nossa Senhora das Necessidades (Sernancelhe): uma primeira análise artefactual Telma Susana O. Ribeiro

${ }_{1141}$ A cividade de Bagunte. O estado atual da investigação Pedro Brochado de Almeida

1153 Zoomorfos na cerâmica da Idade do Ferro no NW Peninsular: inventário, cronologias e significado Nuno Oliveira / Cristina Seoane

1163 Vasos gregos em Portugal: diferentes maneiras de contar a história do intercâmbio cultural na Idade do Ferro

Daniela Ferreira

1175 Os exotica da necrópole da Idade do Ferro do Olival do Senhor dos Mártires (Alcácer do Sal) no seu contexto regional

Francisco B. Gomes

\section{Antiguidade Clássica e Tardia}

1191 O uso de madeira como combustível no sítio da Quinta de Crestelos (Baixo Sabor): da Idade do Ferro à Romanização Filipe Vaz / João Tereso / Sérgio Simões Pereira / José Sastre / Javier Larrazabal Galarza / Susana Cosme / José António Pereira / Israel Espi

1207 Cultivos de Época Romana no Baixo Sabor: continuidade em tempos de mudança? João Pedro Tereso / Sérgio Simões Pereira / Filipe Santos / Luís Seabra / Filipe Vaz

1221 A casa romana na Hispânia: aplicação dos modelos itálicos nas províncias ibéricas Fernanda Magalhães / Diego Machado / Manuela Martins

1235 As pinturas murais romanas da Rua General Sousa Machado, n. ${ }^{5}$ 1, Chaves José Carvalho

1243 Trás do Castelo (Vale de Mir, Pegarinhos, Alijó) - Uma exploração agrícola romana do Douro

Tony Silvino / Pedro Pereira

1255 A sequência de ocupação no quadrante sudeste de Bracara Augusta: as transformações de uma unidade doméstica Lara Fernandes / Manuela Martins

1263 Os Mosaicos com decoração geométrica e geométrico-vegetalista dos sítios arqueológicos da área do Conuentus Bracaraugustanus. Novas abordagens quanto à conservação, restauro, decoração e datação Maria de Fátima Abraços / Licínia Wrench

1277 “Casa Romana” do Castro de São Domingos (Cristelos, Lousada): Escavação, Estudo e Musealização Paulo André de P. Lemos

1291 A arqueobotânica no Castro de Guifões (Matosinhos, Noroeste de Portugal): O primeiro estudo carpológico

Luís Seabra / Andreia Arezes / Catarina Magalhães / José Varela / João Pedro Tereso 
1305 Um Horreum Augustano na Foz do Douro (Monte do Castelo de Gaia, Vila Nova de Gaia) Rui Ramos

1311 Ponderais romanos na Lusitânia: padrões, formas, materiais e contextos de utilização Diego Barrios Rodríguez

1323 Um almofariz centro-itálico na foz do Mondego

Marco Penajoia

1335 Estruturas romanas de Carnide - Lisboa Luísa Batalha / Mário Monteiro / Guilherme Cardoso

1347 O contexto funerário do sector da "necrópole NO" da Rua das Portas de S. Antão (Lisboa): o espaço, os artefactos, os indivíduos e a sua interconectividade na interpretação do passado Sílvia Loja, José Carlos Quaresma, Nelson Cabaço, Marina Lourenço, Sílvia Casimiro, Rodrigo Banha da Silva, Francisca Alves-Cardoso

${ }_{1361}$ Povoamento em época Romana na Amadora - resultados de um projeto pluridisciplinar Gisela Encarnação / Vanessa Dias

1371 A Arquitectura Residencial em Mirobriga (Santiago do Cacém): contributo a partir de um estudo de caso Filipe Sousa / Catarina Felício

${ }_{1385}$ O fim do ciclo. Saneamento e gestão de resíduos nos edifícios termais de Mirobriga (Santiago do Cacém)

Catarina Felício / Filipe Sousa

1399 Balsa, Topografia e Urbanismo de uma Cidade Portuária Vítor Silva Dias / João Pedro Bernardes / Celso Candeias / Cristina Tété Garcia

1413 No Largo das Mouras Velhas em Faro (2017): novas evidências da necrópole norte de Ossonoba e da sua ocupação medieval Ricardo Costeira da Silva / Paulo Botelho / Fernando Santos / Liliana Nunes

1429 Instrumentos de pesca recuperados numa fábrica de salga em Ossonoba (Faro) Inês Rasteiro / Ricardo Costeira da Silva / Paulo Botelho

1439 A Necrópole Romana do Eirô, Duas Igrejas (Penafiel): intervenção arqueológica de 2016 Laura Sousa / Teresa Soeiro

1457 Ritual, descarte ou afetividade? A presença de Canis lupus familiaris na Necrópole Noroeste de Olisipo (Lisboa)

Beatriz Calapez Santos / Sofia Simões Pereira / Rodrigo Banha da Silva / Sílvia Casimiro / Cleia Detry / Francisca Alves Cardoso

1467 Dinâmicas económicas em Bracara na Antiguidade Tardia Diego Machado / Manuela Martins / Fernanda Magalhães / Natália Botica

1479 Cerâmicas e Vidros da Antiguidade Tardia do Edifício sob a Igreja do Bom Jesus (Vila Nova de Gaia) Joaquim Filipe Ramos

1493 Novos contributos para a topografia histórica de Mértola no período romano e na Antiguidade Tardia Virgílio Lopes

\section{8. Época Medieval}

1511 Cerâmicas islâmicas no Garb setentrional "português": algumas evidências e incógnitas Constança dos Santos / Helena Catarino / Susana Gómez / Maria José Gonçalves / Isabel Inácio / Gonçalo Lopes / Jacinta Bugalhão / Sandra Cavaco / Jaquelina Covaneiro / Isabel Cristina Fernandes / Ana Sofia Gomes 
1525 Contributo para o conhecimento da cosmética islâmica, em Silves, durante a Idade Média Rosa Varela Gomes

1537 Yábura e o seu território - uma análise histórico-arqueológica de Évora entre os séculos VIII-XII José Rui Santos

1547 A encosta sul do Castelo de Palmela - resultados preliminares da escavação arqueológica Luís Filipe Pereira / Michelle Teixeira Santos

1559 A igreja de São Lourenço (Mouraria, Lisboa): um conjunto de silos e de cerâmica medieval islâmica

Andreia Filipa Moreira Rodrigues

1571 O registo material de movimentações populacionais no Médio Tejo, durante os séculos XII-XIII. Dois casos de "sunken featured buildings", nos concelhos de Cartaxo e Torres Novas Marco Liberato / Helena Santos / Nuno Santos

1585 O nordeste transmontano nos alvores da Idade média. Notas para reflexão Ana Maria da Costa Oliveira

1601 Sepulturas escavadas na rocha do Norte de Portugal e do Vale do Douro: primeiros resultados do Projecto SER-NPVD

Mário Jorge Barroca / César Guedes / Andreia Arezes / Ana Maria Oliveira

1619 "Portucalem Castrum Novum" entre o Mediterrâneo e o Atlântico: o estudo dos materiais cerâmicos alto-medievais do arqueossítio da rua de D. Hugo, nํ. 5 (Porto) João Luís Veloso

1627 A Alta Idade Média na fronteira de Lafões: notas preliminares sobre a Arqueologia no Concelho de Vouzela

Manuel Luís Real / Catarina Tente

1641 Um conjunto cerâmico medieval fora de portas: um breve testemunho aveirense Susana Temudo

${ }_{1651}$ Os Lóios do Porto: uma perspetiva integrada no panorama funerário da Baixa Idade Média à Época Moderna em meios urbanos em Portugal

Ana Lema Seabra

1659 O Caminho Português Interior de Santiago como eixo viário na Idade Média Pedro Azevedo

1665 Morfologia Urbana: Um exercício em torno do Castelo de Ourém André Donas-Botto / Jaqueline Pereira

1677 Intervenção arqueológica na Rua Marquês de Pombal/Largo do Espírito Santo (Bucelas, Loures)

Florbela Estêvão / Nathalie Antunes-Ferreira / Dário Ramos Neves / Inês Lisboa

1691 O Cemitério Medieval do Poço do Borratém e a espacialidade funerária na cidade de Lisboa Inês Belém / Vanessa Filipe / Vasco Noronha Vieira / Sónia Ferro / Rodrigo Banha da Silva

1705 Um Espaço Funerário Conventual do séc. XV em Lisboa: o caso do Convento de São Domingos da Cidade Sérgio Pedroso / Sílvia Casimiro / Rodrigo Banha da Silva / Francisca Alves Cardoso

\section{9. Época Moderna e Contemporânea}

1721 Arqueologia Moderna em Portugal: algumas reflexões críticas em torno da quantificação de conjuntos cerâmicos e suas inferências históricas e antropológicas Rodrigo Banha da Silva / André Bargão / Sara da Cruz Ferreira

1733 Faianças de dois contextos entre os finais do século XVI e XVIII do Palácio dos Condes de Penafiel, Lisboa

Martim Lopes / Tomás Mesquita 
1747 Um perfil de consumo do século XVIII na foz do Tejo: O caso do Mercado da Ribeira, Lisboa Sara da Cruz Ferreira / Rodrigo Banha da Silva / André Bargão

1761 Os Cachimbos dos Séculos XVII e XVIII do Palácio Mesquitela e Convento dos Inglesinhos (Lisboa)

Inês Simão / Marina Pinto / João Pimenta / Sara da Cruz Ferreira / André Bargão / Rodrigo Banha da Silva

1775 "Tomar os fumos da erua que chamão em Portugal erua sancta». Estudo de Cachimbos provenientes da Rua do Terreiro do Trigo, Lisboa

Miguel Martins de Sousa / José Pedro Henriques / Vanessa Galiza Filipe

1787 Cachimbos de Barro Caulínitico da Sé da Cidade Velha (República de Cabo Verde)

Rodrigo Banha da Silva / João Pimenta / Clementino Amaro

1801 Algumas considerações sobre espólio não cerâmico recuperado no Largo de Jesus (Lisboa) Carlos Boavida

1815 Adereços de vidro, dos séculos XVI-XVIII, procedentes do antigo Convento de Santana de Lisboa (anéis, braceletes e contas)

Joana Gonçalves / Rosa Varela Gomes / Mário Varela Gomes

1837 Da ostentação, luxo e poder à simplicidade do uso quotidiano: arqueologia e simbologia de joias e adornos da Idade Moderna Portuguesa Jéssica Iglésias

1849 Os amuletos em Portugal - dos objetos às superstições: o coral vermelho Alexandra Vieira

1865 Cerâmicas de Vila Franca de Xira nos séculos XV e XVI Eva Pires

1879 «Não passa por teu o que me pertence». Marcas de individualização associadas a faianças do Convento de Nossa Senhora de Aracoeli, Alcácer do Sal Catarina Parreira / Íris Fragoso / Miguel Martins de Sousa

1891 Cerâmica de Leiria: alguns focos de produção

Jaqueline Pereira / André Donas-Botto

1901 Os Fornos na Rua da Biquinha, em Óbidos Hugo Silva / Filipe Oliveira

1909 A casa de Pêro Fernandes, contador dos contos de D. Manuel I: o sítio arqueológico da Silha do Alferes, Seixal (século XVI) Mariana Nunes Ferreira

1921 O Alto da Vigia (Sintra) e a vigilância e defesa da costa Alexandre Gonçalves / Sandra Santos

1937 O contexto da torre sineira da Igreja de Santa Maria de Loures Paulo Calaveira / Martim Lopes

1949 A Necrópole do Hospital Militar do Castelo de São Jorge e as práticas funerárias na Lisboa de Época Moderna Susana Henriques / Liliana Matias de Carvalho / Ana Amarante / Sofia N. Wasterlain

1963 SAND - Sarilhos Grandes Entre dois Mundos: o adro da Igreja e a Paleobiologia dos ossos humanos recuperados

Paula Alves Pereira / Roger Lee Jesus / Bruno M. Magalhães

1975 Expansão urbana da vila de Cascais no século XVII e XVIII: a intervenção arqueológica na Rua da Vitória no 15 a 17

Tiago Pereira / Vanessa Filipe

1987 Novos dados para o conhecimento do Urbanismo de Faro em época Moderna Ana Rosa 
1995 Um exemplo de Arqueologia Urbana em Alcoutim: o Antigo Edifício dos CTT Marco Fernandes / Marta Dias / Alexandra Gradim / Virgílio Lopes / Susana Gómez Martínez

2007 Palácio dos Ferrazes (Rua das Flores/Rua da Vitória, Porto): a cocheira de Domingos Oliveira Maia

Francisco Raimundo

2021 As muitas vidas de um edifício urbano: História, Arqueologia e Antropologia no antigo Recreatório Paroquial de Penafiel Helena Bernardo / Jorge Sampaio / Marta Borges

2035 O convento de Nossa Senhora da Esperança de Ponta Delgada: o contributo da arqueologia para o conhecimento de um monumento identitário João Gonçalves Araújo / N’Zinga Oliveira

2047 Arqueologia na ilha do Corvo... em busca da capela de Nossa Senhora do Rosário Tânia Manuel Casimiro / José Luís Neto / Luís Borges / Pedro Parreira

2059 Perdidos à vista da Costa. Trabalhos arqueológicos subaquáticos na Barra do Tejo Jorge Freire / José Bettencourt / Augusto Salgado

2071 Arqueologia marítima em Cabo Verde: enquadramento e primeiros resultados do projecto CONCHA

José Bettencourt / Adilson Dias / Carlos Lima / Christelle Chouzenoux / Cristóvão Fonseca / Dúnia Pereira / Gonçalo Lopes / Inês Coelho / Jaylson Monteiro / José Lima / Maria Eugénia Alves / Patrícia Carvalho / Tiago Silva

2085 Trabalhos arqueológicos na Cidade Velha (Ribeira Grande de Santiago, Cabo Verde): reflexões sobre um projecto de investigação e divulgação patrimonial André Teixeira / Jaylson Monteiro / Mariana Mateus / Nireide Tavares / Cristovão Fonseca / Gonçalo C. Lopes / Joana Bento Torres / Dúnia Pereira / André Bargão / Aurélie Mayer / Bruno Zélie / Carlos Lima / Christelle Chouzenoux / Inês Henriques / Inês Pinto Coelho / José Lima / Patrícia Carvalho / Tiago Silva

2103 A antiga fortificação de Quelba / Khor Kalba (E.A.U.). Resultados de quatro campanhas de escavações, problemáticas e perspectivas futuras Rui Carita / Rosa Varela Gomes / Mário Varela Gomes / Kamyar Kamyad

2123 Colónias para homens novos: arqueologia da colonização agrária fascista no noroeste ibérico Xurxo Ayán Vila / José Mạ . Señorán Martín 


\title{
AS MUITAS VIDAS DE UM EDIFÍCIO URBANO: HISTÓRIA, ARQUEOLOGIA E ANTROPOLOGIA NO ANTIGO RECREATÓRIO PAROQUIAL DE PENAFIEL
}

\author{
Helena Bernardo ${ }^{1}$, Jorge Sampaio ${ }^{2}$, Marta Borges ${ }^{3}$
}

\begin{abstract}
RESUMO
O trabalho que ora se apresenta sintetiza os resultados da intervenção arqueológica levada a cabo entre Outubro de 2018 e Abril de 2019, no âmbito do Projecto de Recuperação e Restauro do Recreatório Paroquial Penafidelense (freguesia e concelho de Penafiel, distrito do Porto), localizado no núcleo primitivo do lugar de Arrifana de Sousa, da antiga freguesia de S. Martinho de Moazares, hoje em pleno Centro Histórico da cidade de Penafiel. O edifício reveste-se de particular interesse patrimonial pelo conjunto variado de funções que lhe foram destinadas entre o século XIV (?) e a actualidade: albergaria/hospital, capela, sede da Irmandade da Misericórdia e teatro.
\end{abstract}

Palavras-chave: Recreatório Paroquial, Albergaria, Hospital, Capela, Necrópole.

\begin{abstract}
The work presented here summarizes the results of the archaeological intervention carried out between October 2018 and April 2019, within the Recovery and Restoration Project of the Recreatório Paroquial Penafidelense (parish and municipality of Penafiel, district of Porto), located in the primitive nucleus of the place Arrifana de Sousa, in the old parish of S. Martinho de Moazares, today in the heart of the Historic of the city of Penafiel. The building is a particular patrimonial interest due to the varied set of functions that were assigned to it between the $14^{\text {th }}$ century (?) and today: hostel/hospital, chapel, headquarters of the Irmandade $d a$ Misericórdia and theater.
\end{abstract}

Keywords: Recreatório Paroquial, Hostel, Hospital, Chapel, Necropolis.

\section{INTRODUÇÃO}

Este artigo tem por base os resultados dos trabalhos de acompanhamento e subsequente escavação arqueológica levados a cabo no âmbito do Projecto de Recuperação e Restauro do "Recreatório Penafidelense", da autoria dos arquitectos Salomé Campos e Rui Santos da empresa Arché, requerido pela Fábrica da Igreja Paroquial da freguesia de Penafiel e implementado em parceria com a Câmara Municipal/ Museu Municipal (Figura 1).

O edifício, em vias de classificação (DR, 2.. ${ }^{a}$ serie,
Anúncio n.ำ 126/2018, de 26 de Julho), encontra-se abrangido pela Área de Protecção e Enquadramento ao Património relativa ao Centro Histórico da Cidade de Penafiel (Resolução do Conselho de Ministros n. $.163 / 2007$, de 12 de Outubro), beneficiando ainda da Zona de Protecção da Igreja paroquial de S. Martinho (MN desde 1910), que lhe é fronteira.

A intervenção arqueológica foi da responsabilidade dos signatários, coadjuvados pela antropóloga Marta Borges, na sequência da detecção de vestígios osteológicos humanos. A área a intervencionar foi dividida em três zonas $\left(\mathrm{Z}_{1}, \mathrm{Z}_{2}\right.$ e $\left.\mathrm{Z}_{3}\right)$, tendo os traba-

\footnotetext{
1. Museu Municipal de Penafiel; helena.bernardo@cm-penafiel.pt

2. Museu Municipal de Penafiel; jorge.sampaio@cm-penafiel.pt

3.mspborges@gmail.com
} 
lhos de escavação incidido apenas nas duas primeiras, dada a reduzida potência estratigráfica na $Z_{3}$, que apenas foi alvo de acompanhamento.

Optámos por não aprofundar a análise da arqueologia da arquitectura, tal como os aspectos relacionados com a adaptação a teatro e os usos que se seguiram, por os considerarmos demasiado extensos para o presente artigo, privilegiando os dados relativos às ocupações mais antigas deste espaço construído. Também não foi possível concluir em tempo útil a análise antropológica dos vestígios osteológicos que serão apresentados posteriormente.

\section{APONTAMENTO HISTÓRICO}

O desenvolvimento do lugar de Arrifana de Sousa (hoje cidade de Penafiel), documentado pela primeira vez em 1258 (PMH, Inq., p. 593), elevado a vila em 1741, e a cidade e sede de bispado em $1770^{4}$, beneficiou da sua localização na margem de um caminho medieval, com princípio na Porta de Cimo de Vila, no Porto, que seguia para as Beiras e Trás-os-Montes, sendo também preferencialmente utilizado nas peregrinações a Roma (Almeida, 1968, pp. 173-174). Ao longo desta stratam (PMH, Inq., p. 592), são referenciados albergarias, hospitais e gafarias para assistência a viandantes, doentes e peregrinos. Na povoação de S. Martinho de Moazares (Penafiel), dá-se nota da existência de uma albergaria que estava dedicada ao Espírito Santo (Almeida, 1968, pp. 173-174). Na verdade, encontrámos referências a uma Albergaria do Espírito Santo nas Memórias do Mosteiro de Bustelo, no Testamento de Martim Rodrigues Leitão, Cavaleiro de Lodares, Vezinho de Santarem, datado de 27 de Maio de 1329, que deixa à Albergaria do Espirito santo, á de Santa Maria de Palhains, de S. João eá da Trindade sinco sinco soldos (Dias, 2007, pp. 55-56). Embora o testamento não identifique a povoação, dois autores penafidelenses (Miranda, 1937, pp. 24-25; Mendes, 1992, p. 10) localizam-na no burgo de Arrifana de Sousa e identificam-na com parte do edifício objecto deste estudo. Assim, a albergaria já estaria em funcionamento antes de 1329. A sua implantação nas traseiras de uma capela voltada para a Estrada Real/rua Direita e face à do Espírito Santo, já edificada em 1399 (Dias, 2007, pp. 78-79), sobre a

4. Para aprofundar a história e evolução do lugar de Arrifana de Sousa no município de Penafiel consultar SOEIRO, 1993; SANTOS 2005; BERNARDO, 2012. qual foi construída a igreja matriz, em 1569/1570, parece reforçar essa possibilidade.

Tal como a maioria das suas congéneres, desta albergaria descenderá o primeiro hospital do lugar, na zona apelidada de of fraguedo (Ferreira, 1991-1992, pp. 231), com existência confirmada em 1466 (PT/ADPRT/MON/CVSMBPNF/ooor, fl. 172v, n.p. $258 \mathrm{v}$ a 259v) (Figura 2).

Em 1509 (Compromisso... 1788, pp. 22-23; Sousa, 1983, pp. 22-27; Fernandes, 2016, pp. 56-57), a capela agora intervencionada, que tinha como orago Nossa Senhora das Dores (Ferreira, 1991/1992, p. 231), com o hospital anexo, foi escolhida para sede da recém-criada Irmandade da Misericórdia, tendo esta permanecido aí até à construção da nova igreja no lugar das Chans (praça Municipal), obra que decorreu entre 1621 e 1631 (Miranda, 1927, p. 40; Miranda, 1928, pp. 85-89; Soeiro, 1993, vol. 1, pp. 256-26o). Em 1896, Simão Rodrigues Ferreira refere que Este estabelecimento [Santa Casa da Misericórdia] começou na casa aonde é hoje o teatro, defronte da egreja Matriz; tinha na frente a capella de N. Senhora das Dores, e para o lado de traz, casa aonde haviam quartos para os transeuntes no andar de baixo, e em cima alguns para poucos doentes, e para os enfermeiros, tudo porem pequeno, emuito acanhado (Ferreira, 1991/1992, p. 231). Por contrato de 1 de Outubro de 1619, a Irmandade deu a Capela do Hospital a Amaro Moreira, licenciado na Universidade de Coimbra, pároco em Ermelo (Mondim de Basto) e provedor da Santa Casa da Misericórdia de Penafiel, em 1627 (Miranda, 1928, pp. 88-89; Sousa, 1985, pp. 46), por não se haver dado ainda a alguem, passando a ser privativa, e que este pretendia modificar e usar como panteão para si e para a sua família (Almeida, 1815, p. 53). O contrato refere ser capela pequena e antiga, e talvez por essa razão não tenha sido cumprido (Fernandes, 2009, pp. 42-46), optando Amaro Moreira por construir o novo templo.

Se nesta ocasião não houve lugar a obras de monta, exceptuando talvez no hospital, alvo de trabalhos de pedraria em 1632 (Garcia, 2001, vol. 2, Doc. n. ${ }^{\circ}$ 19), o mesmo não se poderá dizer dos anos seguintes. Em 1641, o tecto da Capela do Hospital ameaçava ruína pelo que, a 24 de Agosto de 1642, os Irmãos da Misericórdia deliberam proceder à sua reconstrução e que se fisese a capella de novo, trabalhos que terão alterado profundamente o edifício (Garcia, 2001, vol. 2, Doc. n.ำ 101 e 102; Garcia, 2009, pp. 95-96; Fernandes, 2009, p. 85). Este empenho em reformar 
a capela terá recebido impulso com uma apreciável doação, feita em 1637, por António Vaz Ferreira, provedor em 1623 (Sousa, 1985, p. 46), e da mulher, Ana de Meireles (Garcia, 2001, vol. 2, Doc. n.ํ9ㅇ). A reformulação inspirar-se-ia na fachada da nova igreja da Misericórdia, iniciada em 1621; também se mudaria o orago para Senhor do Hospital (Garcia, 2009, p. 100) (Figura 3). Isabel Bessa Garcia refere que a capela original apresentaria uma feição gótico-manuelina, coetânea da antiga e fronteira igreja do Espírito Santo e a fachada posterior, do hospital, vestígios estilísticos manuelinos, desconhecemos, no entanto, com que fundamento (Garcia, 2001, vol. 1, p. 81). Hoje, no alçado de alvenaria de granito pobre, despido de rebocos, vários "agrafos" de ferro denunciam as dificuldades em se suster. Observam-se também vãos encerrados, outros abertos de novo e, na linha do beiral, parte de uma goteira em pedra de secção circular.

Falecido António Vaz Ferreira, a 4 de Agosto de 1644 (PT/ADPRT/PRQ/PPNF24/oo3/ooora/mo224, fl. 156), a sua viúva e o filho, Frei José de Meireles, estabelecem um novo contrato, a 27 de Setembro de 1648 (Garcia, 2001: vol. 2, Doc. n.o 96). Nele se estipula a doação de uma quantia para ajuda do retábulo e de uma cruz de prata com a relíquia do Santo Lenho, e várias propriedades, incluindo a herdade da Folha (Arcozelo/ Novelas, Penafiel). Como contrapartidas recebiam missas quotidianas pelos familiares e por si, quando falecessem, celebradas na Capela do Senhor do Hospital, e também metade deste templo (da grade pera dentro somente se comprehende esta doação [...] com o Christo que nella está), passando a panteão de família, para Ana de Meireles e herdeiros, os descendentes dos seus irmãos, Jerónimo e Ângela de Meireles, e os do seu marido (Garcia, 2001, vol. 2, Doc. n. 96 e 97 ).

Nos anos seguintes, a Misericórdia encetaria novas obras de beneficiação da casa do hospital e enfermaria (Garcia, 2001, vol. 2, Doc. n.ำ 103). Realçamos a decisão (23 de Abril de 1656) de abrir sepulturas à entrada da capela para os pobres falecidos no hospital (Garcia, 2001, vol. 2, Doc. n.․ 104). Contudo, os registos de óbitos da paróquia de S. Martinho nunca referem enterramentos no adro desta capela. Os pobres, estrangeiros, peregrinos e doentes que faleciam em Arrifana, alguns com cartas de guia de outras Misericórdias, eram enterrados no adro da matriz, apelidado cemitério paroquial ou semiterio adro dos peregrinos por cima do Cruzeiro de fora da igreja paroquial (PT/ADPRT/PRQ/PPNF24/Oo3/Ooo2, fl. 401v e 428). Entre 1691 e 1772, foram aí sepultadas 27 pessoas $^{5}$, das quais apenas oito tinham falecido no hospital de passageiros de Arrifana ${ }^{6}$. Entre $22 \mathrm{de} \mathrm{Ou}$ tubro de 1642 e 14 de Novembro de 1833 , registámos 173 falecidos no Hospital e nenhum foi sepultado na sua Capela.

De acordo com a documentação disponível, entre os séculos XVII e XIX, foram inumados 24 defuntos no interior da capela ${ }^{7}: 20$ com registo de óbito na paróquia de S. Martinho; três (Ana de Meireles, o Capitão Baltasar Barbosa de Meireles e a mulher, Maria Vieira) apenas mencionados na vedoria de 1749, que descreve os epitáfios das suas sepulturas na capela-mor. Em relação ao ex-provedor António Vaz Ferreira, o registo de óbito da paróquia arrifanense não refere o local de sepultura, pelo que também considerámos as informações do mencionado tombo.

Ao longo da segunda metade do século XVII e primeira do XVIII, realizam-se pequenas obras de manutenção. Em 1706, António Carvalho da Costa faz uma simples menção a Hum Hospital, em que se recolhem os passageiros, \& nelle huma Imagem de Christo crucificado, que faz muitos milagres (Costa, 1706, p. 384). Já a vedoria realizada a 22 de Maio de 1749, um tombo para efeyto de medir e comfrontar a capella e hospital realizado pelo Juiz de Fora e do Tombo da Misericórdia, por requerimento do Procurador do mesmo (PT/AMPNF/SCMP/D/Oo2/ Lvo1 a 04, fl. 57-65, transcrito em Garcia, 2001, vol. 2, Doc. n.․ำ 109) descreve com pormenor toda a estrutura construída bem como o seu interior. Considerando que, até à transformação do edifício em teatro, em 1844, não se efectuaram outras obras

5. PT/ADPRT/PRQ/PPNF24/oO3/ooo2, fl. 311v, 320v, 322, 323v, 325v, 326, 327, 358, 361, 369, 309v-310, 321v, 398v, 401v, 428, 431v; PT/ADPRT/PRQ/PPNF24/o03/ooo4, fl. 215v,300,30ov; PT/ADPRT/PRQ/PPNF24/Oo3/oo18, fl. 79v-8o, 103v, 104-104v, 113v, 122.

6. PT/ADPRT/PRQ/PPNF24/oo3/ooo2, fl. 322, 323v, 326, 361, 401v, 428; PT/ADPRT/PRQ/PPNF24/oo3/ooo6, fl. 300; PT/ADPRT/PRQ/PPNF24/O03/oo18, 104-104v, 122.

7.PT/ADPRT/PRQ/PPNF24/oo3/ooo2,fl.323v,347v,378v, 440, 454, 498v; PT/ADPRT/PRQ/PPNF24/oo3/ooo3, fl. 15V, 16, 33V; 45-45V, 52-52v, 54v, 61, 131v; PT/ADPRT/PRQ/ PPNF24/Oo3/ooo5, fl. 266v; PT/ADPRT/PRQ/PPNF24/ 003/oo18, fl. 12v, 559; PT/ADPRT/PRQ/PPNF24/Oo3/ oo19, fl. 107v, 144; PT/ADPRT/PRQ/PPNF24/oo3/oo2o, fl. 129 . 
de fundo, a vedoria deverá espelhar o resultado das obras de meados do século XVII. Assim, a capela apresentaria uma fachada de feição dórica, com portal de padieira, com pilastras e cornija encimada por um pequeno frontão. Acima deste conjunto, tinha um nicho com a Nossa Senhora da Caridade, ladeado por duas frestas com grades e sobrepujado pelo óculo com rollwerk, de gosto maneirista nórdico, com uma enjunta em ressalto de cada lado (Figura 4). O telhado de duas águas era rematado por uma cruz na empena e ladeado por pirâmides dóricas, com uma torreleta sineira com abertura dupla no lado esquerdo (Garcia, 2001, vol. 1, p. 85). De acordo com uma nota de despesa, a capela teria apenas um sino, cuja corrente necessitou de concerto em 1699; a vedoria de 1749 refere seu campanario com sua garrida aparelhada (PT/AMPNF/SCMP/D/oo2/ Lvo1 a 04, fl. 57-65). Garrida era um sino pequeno que se tangia para ultimo sinal do principio dos officios divinos (Bluteau, 1713, tomo IV, p. 35).

Também António de Almeida conheceu o edifício em funcionamento, tendo considerado a capela pequena e a sua constituição interna algum tanto rustica e antiga e informa que, no hospital, há commodo somente para seis doentes, [...] e ser esta caza mais albergaria do que Hospital, para recolher pobres, que passão com carta de guia de humas Mizericordias para as outras, dando lhes sustento enquanto se demorão, e ate cavalgadura sendo indispensável (Almeida, 1815, p. 50-53).

Em 1836, as funções do velho Hospital, bem como as imagens da Capela, foram transferidas para as dependências do Convento de Santo António dos Capuchos (Beça, 1896, pp. 115, 133-134), deixando o templo sem uso (Soeiro, 1993, vol. 1, pp. 267 e 423). Logo após a mudança, terá surgido a ideia de se fazer aí um teatro e o edifício foi então aforado à Sociedade Phylo-dramática Penafidelense (Beça, 1896, pp. 135-136), que adaptou o espaço, tendo sido apagados todos os traços da sua antiga função, restando apenas alguns elementos da fachada, como a moldura rollwerk do óculo do frontão (Soeiro, 1993, vol. 1, p. 267). Inicialmente, o palco localizava-se junto à rua Direita e o público entrava pelo quelho, nas traseiras, disposição alterada em 1857/1858, passando $\mathrm{o}$ acesso à sala de espectáculos a fazer-se pela rua principal (Beça, 1896, pp. 135-138; Soeiro, 1993, vol. 1, pp. 423-426; Melo, 1927, p. 26; Melo, 1933, pp. 9o, 93-94), aspecto que se manteve e é hoje alvo do restauro. No interior, o edifício apresenta duas linhas de balcões em U suportados por estrutura e pilares em ferro, com gradeamentos do mesmo material, o primeiro com a data 1858 no centro e o segundo com as armas da cidade (Figura 5).

\section{RESULTADOS}

\subsection{Estratigrafia (Figura 6)}

Após a remoção dos pavimentos actuais, na $\mathrm{Z}$ foram detectados estratos relacionados com alterações recentes da soleira da porta principal (UE2O1 a 204, 208) e com remodelações do pavimento e adaptações do edifício, que afectaram grande parte desta zona, em particular as sepulturas 12/13 (UE211), bem como os fossos (UE227 e 228). Unidades constituídas por uma amálgama de espólio de diferentes cronologias e fragmentos de um pavimento de betão. Registou-se também a vala de fundação da parede Norte das bilheteiras (que separa a Z1 da Z2), em alvenaria de granito (a restante estrutura, que se desenvolvia para a Z2, era em madeira) (UEo11 e 205). A esta parede estavam adossadas as escadarias de madeira de acesso aos andares superiores e aos balcões e, sob estes degraus, as camadas de preparação constituídas por lajes de granito, algumas com entalhes e restos de reboco, reaproveitadas de outras construções ou da demolição da estrutura interior da antiga capela (UE248, 249, 256, 257). Após a remoção de todas estas camadas de cronologia contemporânea, estavam as várias sepulturas abertas no substrato geológico, matéria ainda a desenvolver.

Em vários locais da Z1, sobre o afloramento, foram ainda detectados vestígios de um sedimento preto muito compacto (UE225 e 226), um provável nível de circulação, com nódulos de argamassa amarela (e, no caso da primeira UE, ossos de fauna e granito de pequeno módulo rubefactos), cortada pelas sepulturas 15 e 16 (UE242 e 245) e pela UE223. Esta última corresponde à vala de fundação do alicerce da parede da fachada, constituído por uma fiada de pedras com bom acabamento, em particular no ângulo SO desta zona, e que não se encontra alinhado com o alçado actual. Por sua vez, esta vala foi aberta na já referida camada preta (UE226), onde se recolheu um ceitil atribuível aos reinados de D. Manuel I/ D. João III (?) (1495-1521/1521-1557) $)^{8}$.

Neste mesmo espaço $(\mathrm{ZI})$, próximo da entrada prin-

8. Agradecemos a disponibilidade do Professor Doutor Mário Barroca para a classificação das moedas. 
cipal, foram ainda registados um fosso e negativos de outro, este muito destruído, de contorno subcircular e origem antrópica, escavados no saibro (UE227 e 228). O que se encontra mais bem preservado, apresenta uma profundidade máxima aproximada de $0,72 \mathrm{~m}$, cerca de 1,10 $\mathrm{m}$ de diâmetro, na zona mais larga das paredes convexas, e $0,75 \mathrm{~m}$ de fundo, com uma provável rampa de acesso (ou canal de alimentação e ventilação?) voltada para a única entrada de ar. Na estrutura identificada como UE227, as paredes apresentam-se avermelhadas, coloração possivelmente resultante da exposição a altas temperaturas, facto também atestado pela presença de pequenos carvões na sua base, embalados numa camada de cerca de $2 \mathrm{~cm}$, compacta e de cor castanha escura (UE265). Estas estruturas, que foram muito afectadas pela abertura das sepulturas 12/13 e 15 e pelas obras de adaptação do imóvel, poderão ser contemporâneas dos vestígios do piso mais antigo (UE225 e 226), situado directamente sobre o substrato geológico, onde foram recolhidos fragmentos de louça preta e um ceitil ilegível (c. 1438-1578). A tonalidade escura deste sedimento talvez seja resultante da acção do forno de fundição do metal que era posteriormente vertido no molde, no interior do fosso.

Embora sem qualquer outro indício, consideramos a possibilidade de se estar perante negativos de fossos de fundição de sinos. Servem-nos de referência os exemplares destas estruturas identificados em várias escavações arqueológicas, até 2006, num total de 15 fossos (Sebastian, 2006, p. 19-20), nomeadamente no Mosteiro de Pombeiro (Felgueiras), onde, até ao século XVI, os sinos eram fundidos in loco por mestres sineiros itinerantes (Erasun Cortés, 2008, p. 145) e segundo processos tradicionais quase inalterados até aos séculos XIX-XX, prática que se manteve desde, pelo menos, o século VIII até meados do século XIX, paralelamente às oficinas fixas (Sebastian, 2006, p. 11; Pinto, 2019, pp. 77-95; Erasun Cortés, 2007, p. 104). Esta possibilidade é reforçada pela localização das estruturas no interior da capela, que convinha ao sigilo da arte, nas proximidades da porta principal, única entrada do ar necessário à combustão, e junto da torre sineira, facilitando o transporte e colocação dos sinos no lugar definitivo, como era usual (Erasun Cortés, 2007, p. 99).

$\mathrm{Na} Z$ 2, sob a tijoleira, registou-se um depósito de terra de coloração amarela, muito saibrosa (UEoo2), resultante de obras mais recentes, que acumula detritos da antiga capela (azulejos) e do teatro (rebo- cos pigmentados) e "encosta" às lajes que suportam os prumos do primeiro balcão. Segue-se a UEoo4, um sedimento castanho claro, muito solto, que ainda inclui materiais recentes, como tijolo, mas também vestígios osteológicos, pregos, e onde foi aberta uma vala para a colocação de um tubo de esgoto (UEoo5 a 007), que atravessou toda a $\mathrm{Z}_{2}$ e afectou várias sepulturas.

A adaptação a teatro, levada a cabo em 1857/1858, obrigou à remoção do pavimento até ao afloramento, considerando que as valas para colocação das lajes que suportam os prumos do primeiro balcão foram abertas directamente no substrato geológico. Algumas afectaram mesmo os negativos dos barrotes de um soalho que relacionamos com a primeira fase desta sala de espectáculos (1844). Este chão de madeira, também visível na Z1, foi colocado directamente sobre sepulturas destruídas, provavelmente na mesma altura, até porque, em vários dos enchimentos revolvidos, encontramos partes dos azulejos da capela do século XVII (Sep. 1, 8, 10 e 18).

$\mathrm{Na} Z$ 2, há também a registar dois alinhamentos de pedras talhadas e de grande porte, provavelmente para suporte da estrutura em madeira da boca de cena (UEoo3 e 029). Sob a camada de enchimento da vala associada à estrutura UEo29, foi identificada uma pequena vala circular (UE127, 128), que continha um crânio. Este vestígio osteológico encontra-se a cerca de 6 metros das sepulturas mais próximas, registo para o qual não encontrámos explicação. A construção destes "muros" também afectou um estrato de terra preta com alguma compactação e nivelamento, circunscrito à parte mais a Norte da Zona 2 (UEo32 e 024?), também interpretado como de circulação. Nesta camada foi recolhido o maior número de fragmentos de cerâmica.

A estratigrafia da $Z_{3}$ é constituída apenas por uma camada de entulhos que serviu para nivelar o piso de circulação em betão, a que se segue um estrato muito fino, sobre o nível geológico, que poderá corresponder a um pavimento em terra batida, onde registámos alguns negativos de estruturas, possivelmente em madeira (para instalação de soalho?). Os negativos no solo parecem relacionar-se com as “juntas vivas" existentes na parede Nascente e aparentemente com ligação à parede Poente. Do mesmo local, o espólio é essencialmente vítreo, correspondente a fragmentos de pequenos frascos de paredes pouco espessas. 


\subsection{Espólio}

A intervenção arqueológica forneceu um variado conjunto de espólio. Entre este, destaca-se o cerâmico, constituído por um total de 1520 fragmentos, dos quais 685 são de materiais de construção e 835 de cerâmica comum utilitária, entre pastas de cozedura oxidante ou vermelhas (359) e as que resultam de cozedura redutora (316) e, embora com menor incidência, a faiança (84), os vidrados de chumbo (71) e a porcelana $(7)$.

Embora a diferença quantitativa seja pouco significativa em relação à louça preta, a vermelha surge em maior número (cântaro, tigelas, panelas e púcaros) que, no seu conjunto, apresenta uma grande diversidade de proveniências, reflectida nas pastas, colorações, acabamentos das superfícies (por vezes brunidas), mas sempre com boa cozedura. No conjunto da louça preta, as pastas variam entre finas, homogéneas e de boa cozedura, e outras mais porosas e grosseiras, em tons acinzentados. Alguns fragmentos são de reduzida dimensão, o que dificulta a análise morfológica, contudo verifica-se o predomínio da forma mais comum, a panela, com muita fuligem, mas de dimensões e perfis variados (algumas com bordo em V, para colocação de testo). Há, também, um assador de castanhas, com pelo menos uma asa, e outros recipientes destinados à preparação de alimentos na lareira. Quer de cerâmica vermelha, quer de louça preta, regista-se um número significativo de fragmentos na UEO32 (102 e 58, respectivamente), que corresponde à camada antrópica mais antiga da Z2. Embora estas produções sejam características dos séculos XVI ao XVIII (Barreira; Dordio; Teixeira 1998, pp. 170-172; Alves \& alii 1998, pp. 189-192), pela análise estratigráfica e do conjunto artefactual, apontamos para um arco temporal mais próximo das centúrias de quinhentos e seiscentos, ou até talvez um pouco anterior, no caso da cerâmica vidrada (Real \& alii, 1995, pp. 177-178).

A faiança é pouco significativa, 66 fragmentos foram recolhidos na camada de entulhos $\left(Z_{3}\right)$, sendo na sua maioria dos séculos XIX e XX. Durante a escavação, apenas foram encontrados 18 , de pequenas dimensões, embora, pelo tipo de decoração, alguns possam remontar ao século XVII (Gomes; Botelho, 2001, pp. 148-149).

A maioria dos fragmentos de azulejo, do total de 93, integra-se cronologicamente no século XVII. Revela tons de azul, amarelo e branco, consentâneos com os que foram localizados in situ no alçado interior
Poente, após picagem dos rebocos, com a data de $1658^{9}$ (Figura 7). Registaram-se partes de cercadura, friso e padrão considerados os mais frequentemente aplicados nesta época (Simões; Oliveira 1997, tomo I, pp. 136-138 (C1), 127 e 131 (F-10); 41-42 (P-101) e 136). $\mathrm{O}$ tombo de 1749 descreve dois painéis situados nas paredes laterais da capela-mor, com as imagens de Nossa Senhora da Apresentação e de Cristo Senhor Ressuscitado, no entanto, não encontrámos qualquer indício figurativo nos fragmentos recolhidos. Restam quatro fragmentos que traduzem dois padrões distintos dos anteriores, três ainda por classificar e um que, embora de pequena dimensão (UEo11), parece apresentar uma decoração mudéjar (?), em corda seca, revestimentos cerâmicos também designados hispanos-mouriscos, muito difundidos entre o último quartel do século XV e a primeira metade do século XVI (Simões; Oliveira 1990: EST. XXIX). No contexto dos enterramentos, para além do espólio osteológico, que trataremos no capítulo relativo à necrópole, foram resgatadas partes de objectos em ligas de cobre, tais como alfinetes e fivelas de calçado, botões, tachas e dobradiças dos caixões (?). Mas também uma verónica, com duas faces gravadas (Mater Dolorosa e Nossa Senhora das Dores) e uma cruz que parece representar o Cristo Bom Pastor, cuja cronologia ainda não foi possível apurar. Entre o espólio numismático encontramos dez ceitis, dois do reinado de D. Afonso V, quatro de D. João III, um atribuível a D. Manuel I/ D. João III (?), outro ao de D. João II (?) e dois de difícil leitura mas que remontarão ao período entre 1438 e 1578 , sensivelmente. Durante o acompanhamento foram ainda recolhidos $\mathrm{XX}$ réis (1884), outro ilegível, e seis escudos (de entre 1957 e 1970). Pregos em ferro, madeira dos caixões, ossos de fauna e vidro estão também representados.

Entre os fragmentos de vidro foram contabilizados 297, tendo sido recolhidos 233 exemplares durante o acompanhamento, na $Z_{3}$. Na maioria destaca-se a pouca espessura das paredes translúcidas, mas alguns permitem identificar várias formas de boiões ou pequenos potes, e mesmo uma tampa, associadas a antigas boticas (Medici, 2014, pp. 370, 372-373). De notar que o espaço deixou de ser utilizado como hospital por volta de 1836 , pelo que estes materiais serão

9. No que resta do padrão, verificámos que este foi recortado para que um fragmento de azulejo com a data gravada com algum objecto perfurante fosse inserido, não sendo esta referência produzida na fábrica. 
anteriores a esta data e a sua localização, no rés-do-chão do espaço identificado como hospital, poderá indicar a área destinada a botica. Nas sepulturas há a registar dois anéis, um verde e outro azul escuro, e ainda um fragmento de outro de cor preta. O uso de anéis de vidro era comum no século XVI entre a população mais remediada, material que substituía os metais mais nobres, sendo frequentes em sepulturas (Medici, 2014, pp. 393-394).

Nos contextos de enterramento destacam-se as contas de terços, rosários ou colares (616 unidades) em madeira, vidro, osso, marfim (?) e azeviche.

\section{NECRÓPOLE}

No total, foram contabilizadas 18 sepulturas abertas no saibro, em diferentes graus de conservação, consequência da maior ou menor afectação a que estiveram sujeitas nas obras de adaptação a teatro. Embora sem evidências de enterramentos estruturados, até porque o pavimento foi rebaixado, sabemos que, no chão da capela-mor, as sepulturas tinham frizoz (vedoria de 1749), que entendemos por algum relevo que as destacava no solo, e que a nave teria lajeado no centro e soalho nas laterais.

A Zı não foi tão afectada pelas intervenções oitocentistas, apenas remexida a sua zona central, como referimos, tendo estes trabalhos afectado, em particular, a vala das sepulturas 12 e 13 que conteria dois enterramentos, um dos quais com o único caixão aqui registado. Nesta área, foram detectadas sete inumações (S12 a S18), que atingem uma profundidade em torno dos $50 \mathrm{~cm}$, quase sempre com o esqueleto total ou parcialmente completo, em conexão anatómica e bom estado de conservação (Figura 8 e 9).

$\mathrm{Na} \mathrm{Z}_{2}$ foram registadas 11 sepulturas ( $\mathrm{S}_{1}$ a Si1) embora, em relação a duas (Sio e Si1), mantenhamos algumas dúvidas, considerando que a sua identificação se baseia em indícios muito ténues. Assim, restam-nos nove com conteúdo osteológico e, entre estas, apenas duas com vestígios de madeira e pregos do caixão ( $\mathrm{S}_{1}$ e $\mathrm{S}_{5}$ ), concluindo-se assim que as restantes sete não dispunham deste invólucro. A profundidade actual das valas varia entre $5 \mathrm{e} 20 \mathrm{~cm}$ e todo o conteúdo apresentava um avançado estado de degradação, numa amálgama indistinta de ossos e tecido, não tendo sido possível a recolha destes vestígios de forma íntegra. Esta situação dever-se-á não só às remodelações do imóvel, mas também à possibilidade de terem sido compactados por um segundo nível de sepulturas entretanto destruídas. O documento de 1749 explica o facto de as sepulturas não se estenderem até à parede Nascente, junto da qual descreve a escadaria do púlpito e, sob esta, a entrada em arco para o corredor de acesso à sacristia e ao hospital.

Todos os enterramentos têm orientação Norte-Sul, tal como a implantação da antiga capela, que também não obedece à orientação canónica, sendo que catorze voltam a cabeça para o altar-mor e três para a porta principal. Três dos sepultados possuíam caixão e os restantes treze terão sido inumados envoltos em sudário, pela ausência de evidências materiais, excepto alguns alfinetes, ou vestidos e calçados. Desta indumentária encontramos fivelas, couro e solas de sapatos, botões e restos de tecidos. (Figura 10).

\section{CONCLUSÕES}

A capela já estaria em funções pelo menos no segundo quartel do século XV (?), considerando a cronologia do espólio numismático recolhido. Contudo, o espaço de implantação, enquanto área edificada, poderá ser de cronologia mais recuada (século XIV?) se considerarmos os fragmentos de vidrado de chumbo de tom verde. A restante cerâmica recolhida nas unidades apoiadas no substrato geológico está muito fragmentada para se retirarem conclusões mais aturadas.

A Irmandade da Misericórdia, sabemos, ter-se-á instalado num templo pré-existente dedicado a Nossa Senhora das Dores, em 1509. O registo do alicerce de uma antiga fachada, com um ligeiro desvio em relação à actual, apenas visível no interior, cuja vala foi aberta na UE226 (e na qual se recolheu um ceitil atribuível aos reinados de D. Manuel I / D. João III), poderá confirmar a realização de obras na fachada ou a construção do edifício original?

Permanece a dúvida relativamente à eventual estrutura de fundição de sinos. A confirmar-se, esta estará relacionada com o templo mais antigo ou com as alterações levadas a cabo pela Misericórdia no início do século XVI? A partir do século XVII, a Irmandade da Misericórdia de Arrifana mantinha organizada a documentação relativa às receitas e despesas (Fernandes, 2016, pp. 55-57) pelo que, certamente, não deixaria de mencionar os gastos com o fabrico de um novo sino para a Capela do Hospital.

Considerando que, em 1648, Ana de Meireles e o filho, José de Meireles, no contrato que estabelecem com a Irmandade da Misericórdia, recebem apenas 
metade da capela, que correspondia ao espaço da capela-mor, da grade pera dentro somente, onde esta viria a ser sepultada, bem como os seus familiares, e que, na vedoria de 1749 se refere que, na nave, com licença do provedor e meza e dando sua esmola se enterra quem tem devossam disso junto do arco da capella, confirma-se que algumas das sepulturas encontradas não pertencem à família dos dotadores. Tendo em conta que na $Z_{1}$, na primeira fase de adaptação a teatro, não houve necessidade de rebaixamento, dado que inicialmente o palco estava localizado nesta área, junto à rua Direita, a maioria das sepulturas ficaram mais bem preservadas, relativamente à Z2. Cremos que, em particular na Z2, um provável segundo nível de enterramentos, sobre os vestígios antes mencionados, terá sido totalmente destruído, possibilidade que poderá explicar o facto de alguns esqueletos estarem completamente esmagados. Por outro lado, a profundidade actual destas sepulturas é insuficiente para albergar um corpo. Alguns enterramentos são anteriores aos registos paroquiais, iniciados a 21 de Julho de 1631, embora apenas o possamos confirmar para as S2, 3 e 18, que forneceram ceitis dos reinados de D. Afonso V e D. João III.

Relativamente à albergaria/hospital, as materialidades não parecem confirmar a sua existência em cronologia tão recuada como o início do século XIV, apontada por alguns autores locais que a identificaram com a Albergaria do Espírito Santo referida nas Memórias do Mosteiro de Bustelo. Contudo, a área envolvente onde estava implantada, bastante alterada ao longo das centúrias, ainda não foi objecto de intervenção arqueológica sistemática.

\section{FONTES}

\section{Fontes documentais}

Arquivo Distrital do Porto (ADPRT) - Convento de S. Miguel de Bustelo.

PT/ADPRT/MON/CVSMBPNF/ooo1 - Prazos, fl. 172v a $173 \mathrm{~V}$ [nova paginação $258 \mathrm{v}$ a 259v].

ADPRT - Registos paroquiais de S. Martinho de Arrifana de Sousa.

PT/ADPRT/PRQ/PPNF24/oo3/ooo1a a /oo6, /oo18 a /OO21.

Arquivo Municipal de Penafiel (AMPNF) - Santa Casa da Misericórdia de Penafiel.

PT/AMPNF/SCMP/D/oo2/Lvo1 a 04, Tombos, 1750, fl. $57-65$.
Fontes impressas

ALMEIDA, António d' (1815) - "Descrição Historica e Topografica da Cidade de Penafiel”, Parte III, In SOEIRO, Teresa (1993) - O Progresso também chegou a Penafiel. Resistência e mudança na cultura material, 1741-1910. Tese de doutoramento, vol. III. Porto: FLUP.

BEÇA, Coriolano de Freitas (1896) - Penafiel Hontem e Hoje: Recordações e impressões. Penafiel: Typ. de «O Penafidelense».

BLUTEAU, Raphael (1713) - Garrida. In Vocabulario Portuguez \& Latino, Tomo IV (1713). Lisboa: Officina de Pascoal da Silva, p. 35 .

Compromisso da Misericórdia de Arrifana de Sousa. Impresso no Anno de 1697. Porto: Offic. de António Alvarez Ribeiro, 1788 .

COSTA, António Carvalho da (1706) - Corografia portugueza [...]. Lisboa: Off. de Valentim da Costa Deslandes, 1706-1712.

DIAS, Fr. Geraldo J. A. Coelho (2007) - Memórias do Mosteiro de S. Miguel de Bustelo (180o-1801) de MEIRELES, Fr. António d'Assunção. Penafiel: Museu Municipal.

FERREIRA, Simão Rodrigues (1991/1992) - “Apontamentos para a historia topografica de Penafiel”, In Penafiel, Boletim Municipal de Cultura, 3.․ㅗ série, n.ㅇ6/7. Penafiel: Câmara Municipal, pp. 223-245.

PMH, Inq. = PORTUGALIAE Monumenta Historica. Inquisitiones, volume I, fascículo IV-V (1897). Lisboa: Academia das Ciências de Lisboa.

\section{BIBLIOGRAFIA}

ALMEIDA, Carlos Alberto Ferreira de (1968) - Vias medievais. Entre Douro e Minho. Dissertação para licenciatura. Porto: FLUP.

ALVES, Francisco J. S.; RODRIGUES, Paulo J. P.; GARCIA, Catarina; ALELUIA, Miguel (1998) - "A cerâmica dos destroços do navio dos meados do século XV. Ria de Aveiro A e zona Ria de Aveiro B. Aproximação tipológica preliminar”, In Actas das 2. ${ }^{\text {as }}$ Jornadas de Cerâmica Medieval e Pós-Medieval. Tondela: Câmara Municipal, pp. 185-210.

BERNARDO, Helena (2012) - Do lugar de Arrifana de Sousa à cidade de Penafiel: Urbanismo e arquitetura (séculos XVI-XVIII). Dissertação de Mestrado. Porto: FLUP, edição policopiada.

BARREIRA, Paula; DORDIO, Paulo; TEIXEIRA, Ricardo (1998) - "200 anos de cerâmica na Casa do Infante: do século XVI a meados do século XVIII”, In Actas das 2. ${ }^{\text {as }}$ Jornadas de Cerâmica Medieval e Pós-Medieval. Tondela: Câmara Municipal, pp. 145-184.

ERASUN CORTÉS, Ricardo (2007) - "Um fosso de fundição de sinos no Mosteiro de Santa Maria de Pombeiro - Felgueiras”, Revista OPPIDUM, n.ํㅜ 2. Lousada: Câmara Municipal de Lousada, pp. 95-114. 
ERASUN CORTÉS, Ricardo (2008) - “A fundição de sinos no Mosteiro de Santa Maria de Pombeiro”, Revista OPPIDUM, número especial. Lousada: Câmara Municipal de Lousada, pp. 131-149.

FERNANDES, Paula Sofia (2009) - "Fundação e consolidação da Misericórdia”, In Misericórdia de Penafiel: 500 anos. Penafiel: Santa Casa da Misericórdia de Penafiel, p. 15-62.

FERNANDES, Paula Sofia Costa (2016) - O Hospital e a Botica da Misericórdia de Penafiel. Penafiel: Santa Casa da Misericórdia.

GOMES, Luís Filipe; BOTELHO, Iva Teles (2001) - "Faianças do séc. XVII num Arrabalde do Porto”, In Itinerário da Faiança do Porto e Gaia, Museu Nacional de Soares dos Reis (Coord). Lisboa: IPM.

GRACIA, Isabel Bessa (2001) - A Arquitectura de raiz clássica no Vale do Sousa. Dissertação de Mestrado. Coimbra: FLUC, edição policopiada.

GRACIA, Isabel Bessa (2009) - “As igrejas da Misericórdia de Penafiel. Um percurso arquitectónico”, In Misericórdia de Penafiel: 500 anos. Um baluarte histórico-cultural. Penafiel: Santa Casa da Misericórdia de Penafiel, pp. 63-124.

MEDICI, Teresa (2014) - Vidros da Terra. O vidro tardomedieval e moderno em Portugal (séculos XIV-XVII). O contributo da arqueologia. Tese de doutoramento. Coimbra: FLUC, edição policopiada.

MENDES, J. J. (1992) - “Da origem, formação e desenvolvimento de Arrifana de Sousa e Penafiel”, 2. ․ Edição. Penafiel: MAIA \& MENEZES.

MELO, Ernesto de (1927) - "Do nosso teatro", In Penha-fidelis, 1.ำ Ano, n.ำ 1. Penafiel: Biblioteca Municipal, composto e impresso na Tipografia Minerva.

MELO, Ernesto de (1933) - Dos Tempos passados. Penafiel: Tipografia de «O Povo de Penafiel».

MIRANDA, Abílio (1928) - "História da Misericórdia de Penafiel”, In Penha-fidelis, 1.․ Ano, n..$^{\circ}$ 5, pp. 83-89; n.ำ 7, pp. 129-131. Penafiel: Biblioteca Municipal.

MIRANDA, Abílio (1937) - “A Freguesia de S. Martinho de Moazares”, Separata dos folhetins de O Penafidelense, Terras de Penafiel, vol. 1, pp. 1-30.

PINTO, Diana Felícia (2019) - De Campanis Fundentis. A fábrica de Fundição de Sinos de Rio Tinto, Relatório de Estágio no âmbito do Mestrado em História da Arte, Património e Cultura Visual apresentado à FLUP. Porto: FLUP, edição policopiada.

REAL, Manuel Luís; DORDIO, Paulo; TEIXEIRA, Ricardo; MELO, Rosário Figueiredo (1995) - “Conjuntos cerâmicos da intervenção arqueológica na Casa do Infante - Porto: elementos para uma sequência longa - séculos IV-XIX", In Actas das 2. ${ }^{\text {as }}$ Jornadas de Cerâmica Medieval e Pós-Medieval. Tondela: Câmara Municipal, pp. 171-186.
SANTOS, Maria José Ferreira dos (2005) - A Terra de Penafiel na Idade Média. Estratégias de ocupação do território (875-1308), Cadernos do Museu, n.ํ1o. Penafiel: Câmara Municipal / Museu Municipal de Penafiel, pp. 5-10o.

SEBASTIAN, Luís (2006) - "A fundição sineira em Portugal, da História à Investigação”, In Actas do 3. Simpósio sobre Mineração e Metalurgia históricas no Sudoeste europeu. Porto.

SIMÕES, J. M. dos Santos; OLIVEIRA, Emílio Guerra de (1997) - Azulejaria Portuguesa em Portugal no século XVII, Tomo I-Tipologia. Lisboa: Fundação Calouste Gulbenkian.

SOEIRO, Teresa (1993) - O Progresso também chegou a Penafiel. Resistência e mudança na cultura material. Tese de Doutoramento. Porto: FLUP, edição policopiada.

SOEIRO, Teresa (1994) - Penafiel. Lisboa: Editorial Presença.

SOUSA, António Gomes de (1983) - “Um livro de Índices da Misericórdia de Penafiel”, Anais da Santa Casa da Misericórdia de Penafiel, Ano 3.․ Penafiel: Santa Casa da Misericórdia.

SOUSA, António Gomes de (1985) - "Galeria dos Provedores da Santa Casa de 1570 a 1669", Anais da Santa Casa da Misericórdia de Penafiel, Ano 5. ‥ Penafiel: Santa Casa da Misericórdia. 


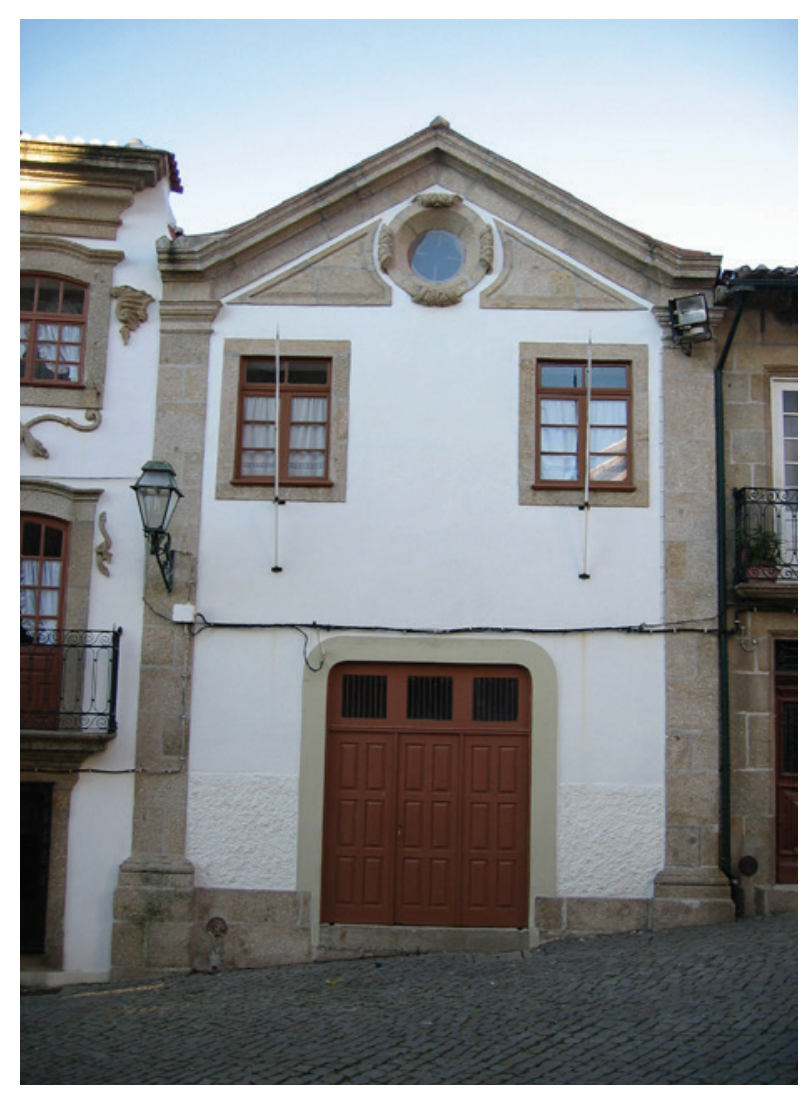

Figura 1 - Recreatório Paroquial (Oficina de Reabilitação GTL, 2006).

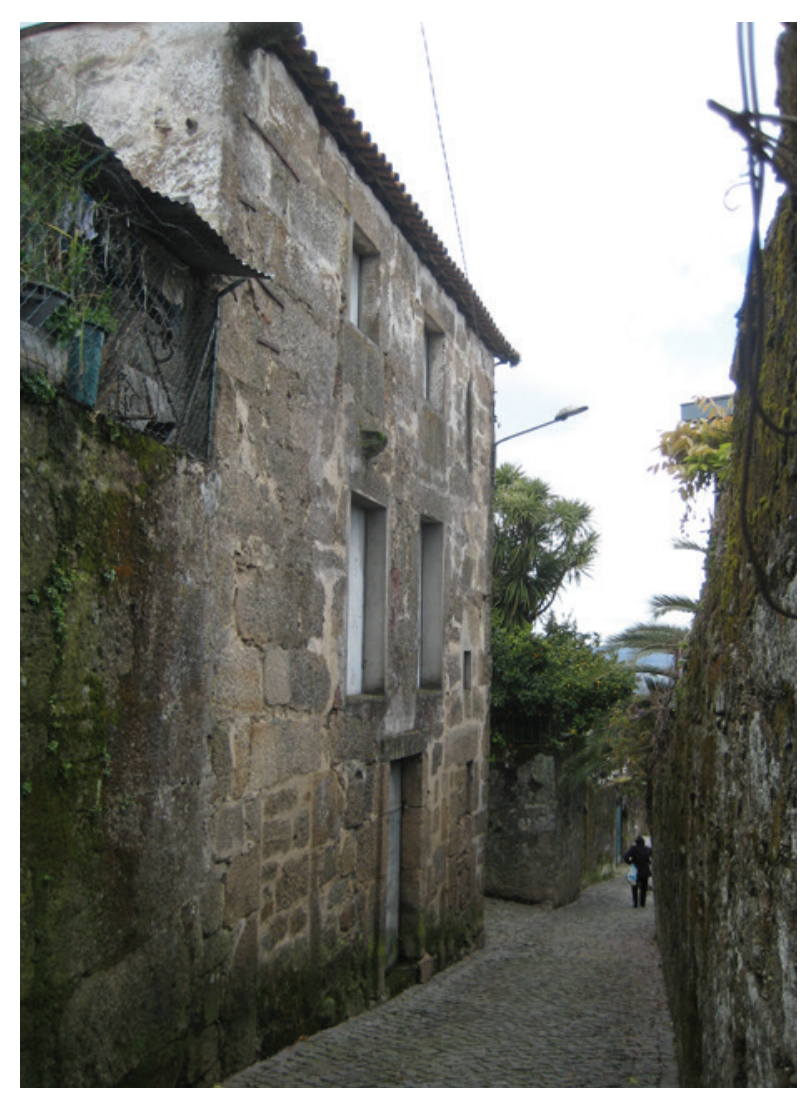

Figura 2 - Fachada do antigo hospital de Arrifana de Sousa.

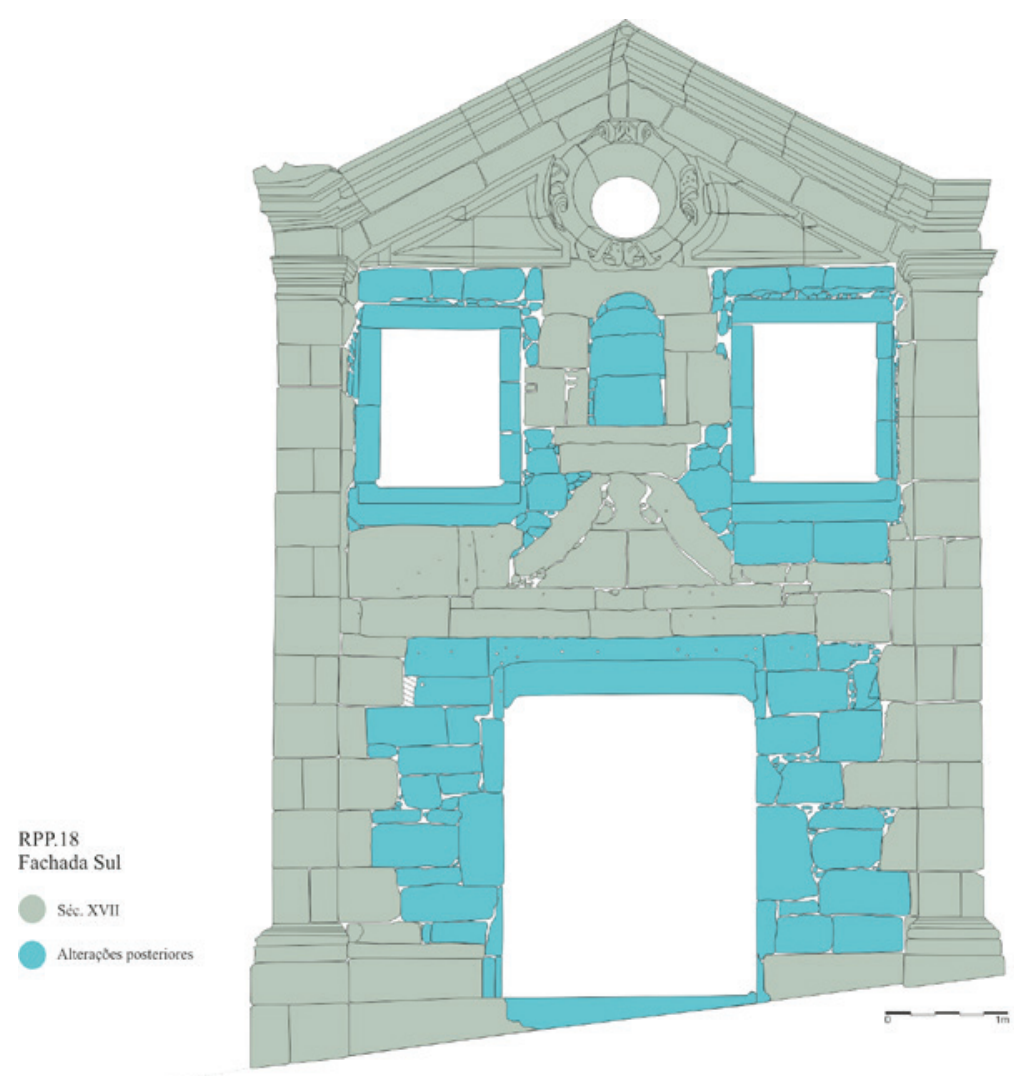

Figura 3 - Alçado principal da antiga Capela do Hospital após remoção do revestimento. 


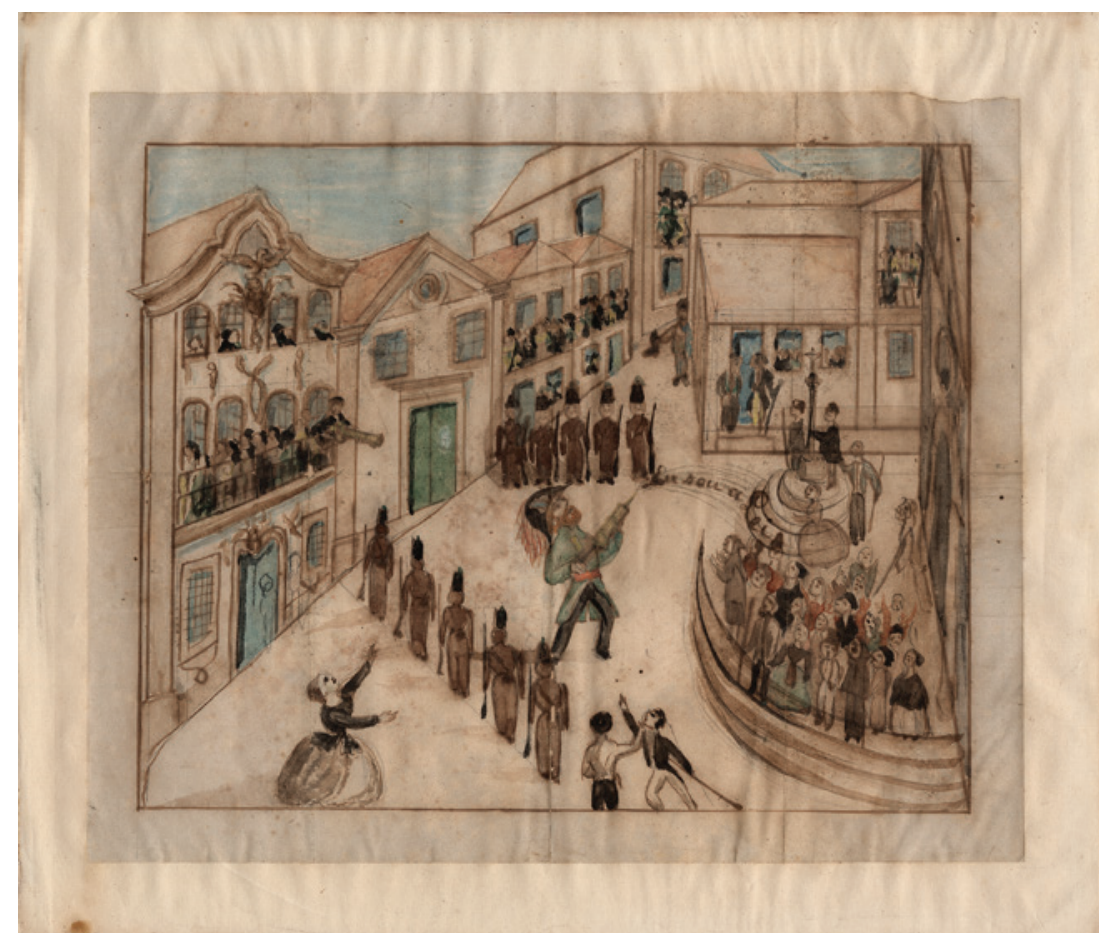

Figura 4 - Registo caricatural de um diferendo ocorrido em 1861 entre o Administrador do Concelho, D. Miguel Vaz Guedes de Ataíde Malafaia Júnior, e o público que se dirigia ao teatro, por aquele ter proibido o espectáculo do dia 1 de Dezembro por ainda não terem sido realizadas as exéquias pelo falecimento do rei D. Pedro V. Junto à igreja matriz vê-se o cruzeiro, atualmente localizado na Quinta da Aveleda, e em frente, a fachada do Recreatório, com o portal da antiga capela (n.. inv.. MMPNF/2009/7908, publicado em Soeiro, 1994, p. 56).

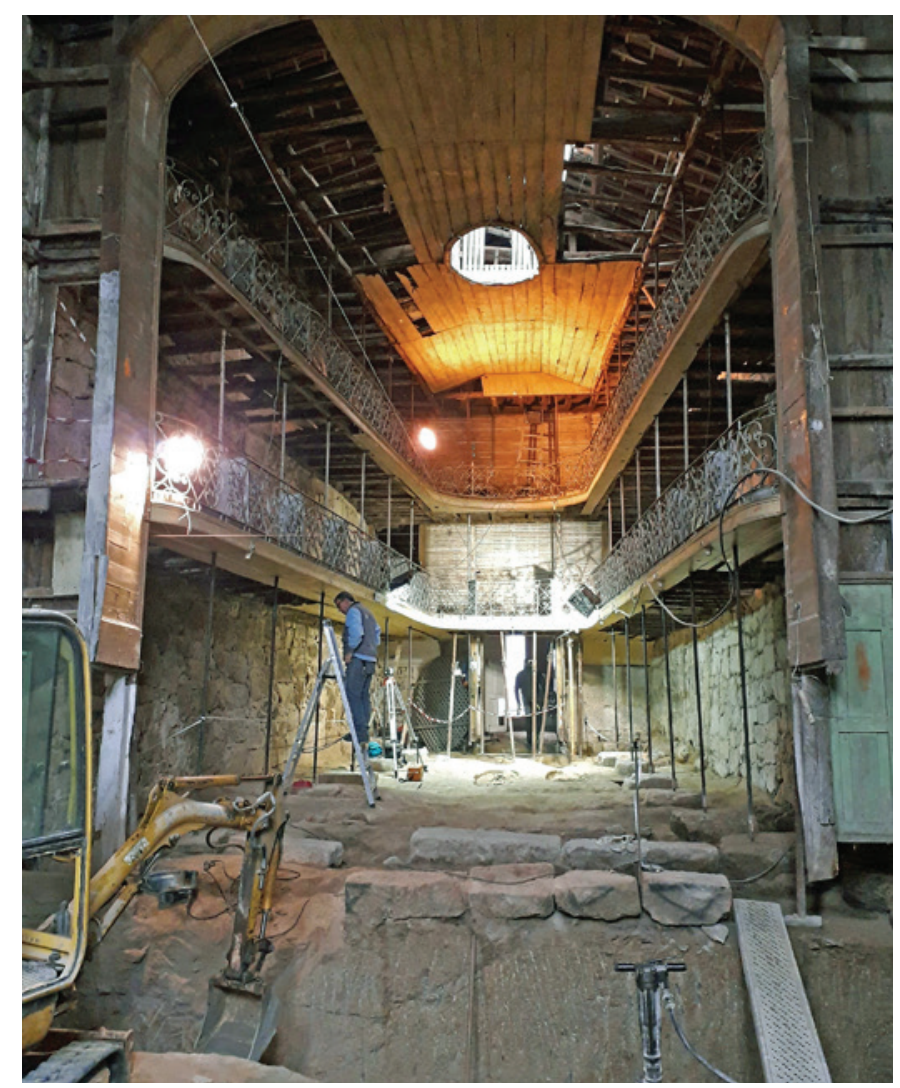

Figura 5 - Interior do Recreatório em obras, com os dois níveis de balcões e lanternim de iluminação. 


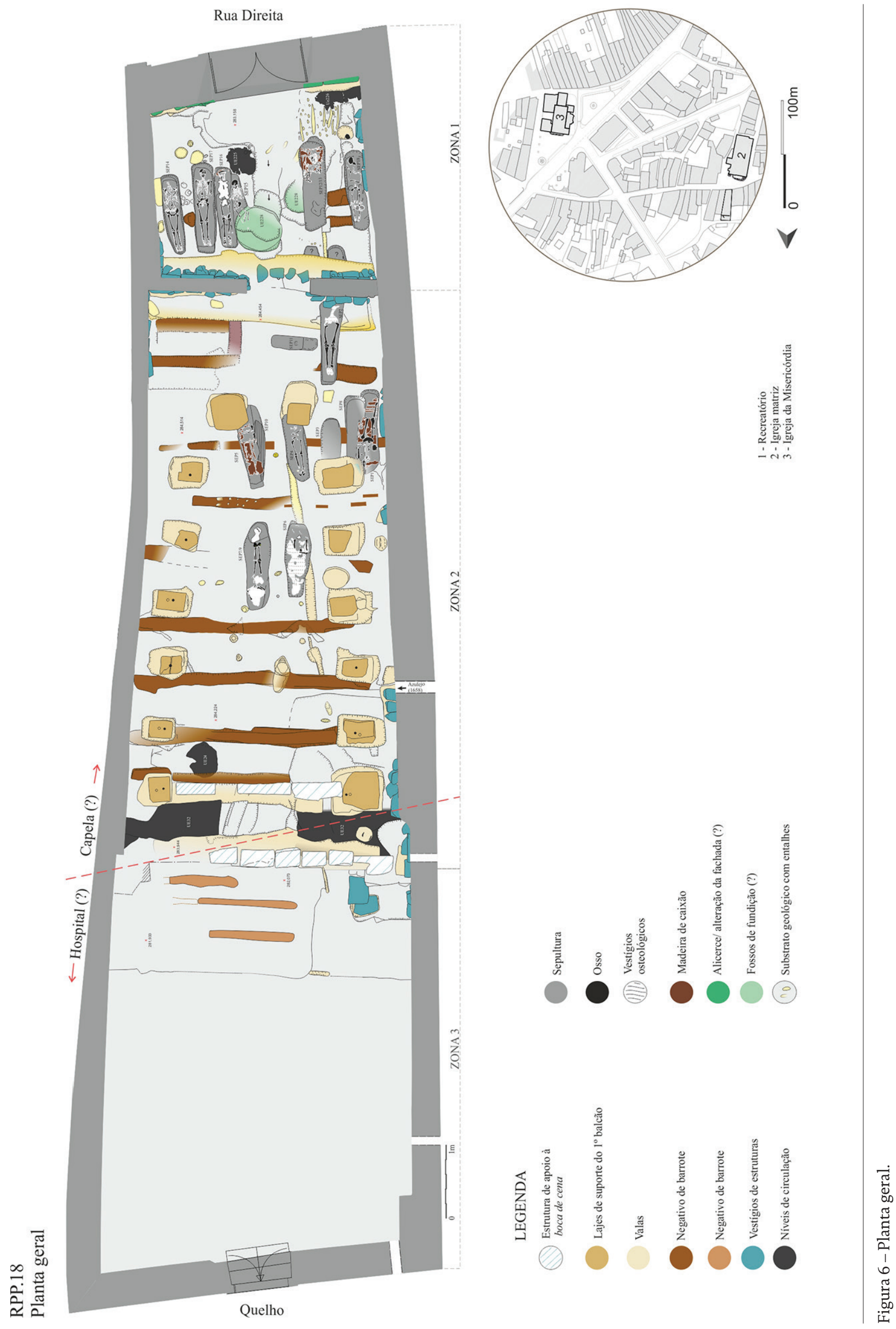




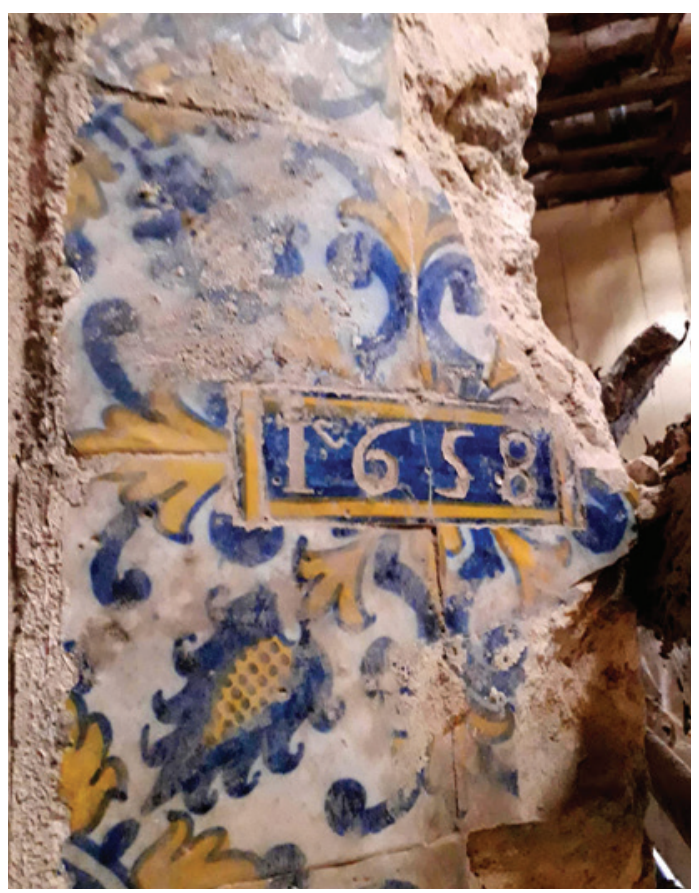

Figura 7 - Parte do padrão azulejar que revestia a antiga capela-mor localizado in situ com a data de 1658 .

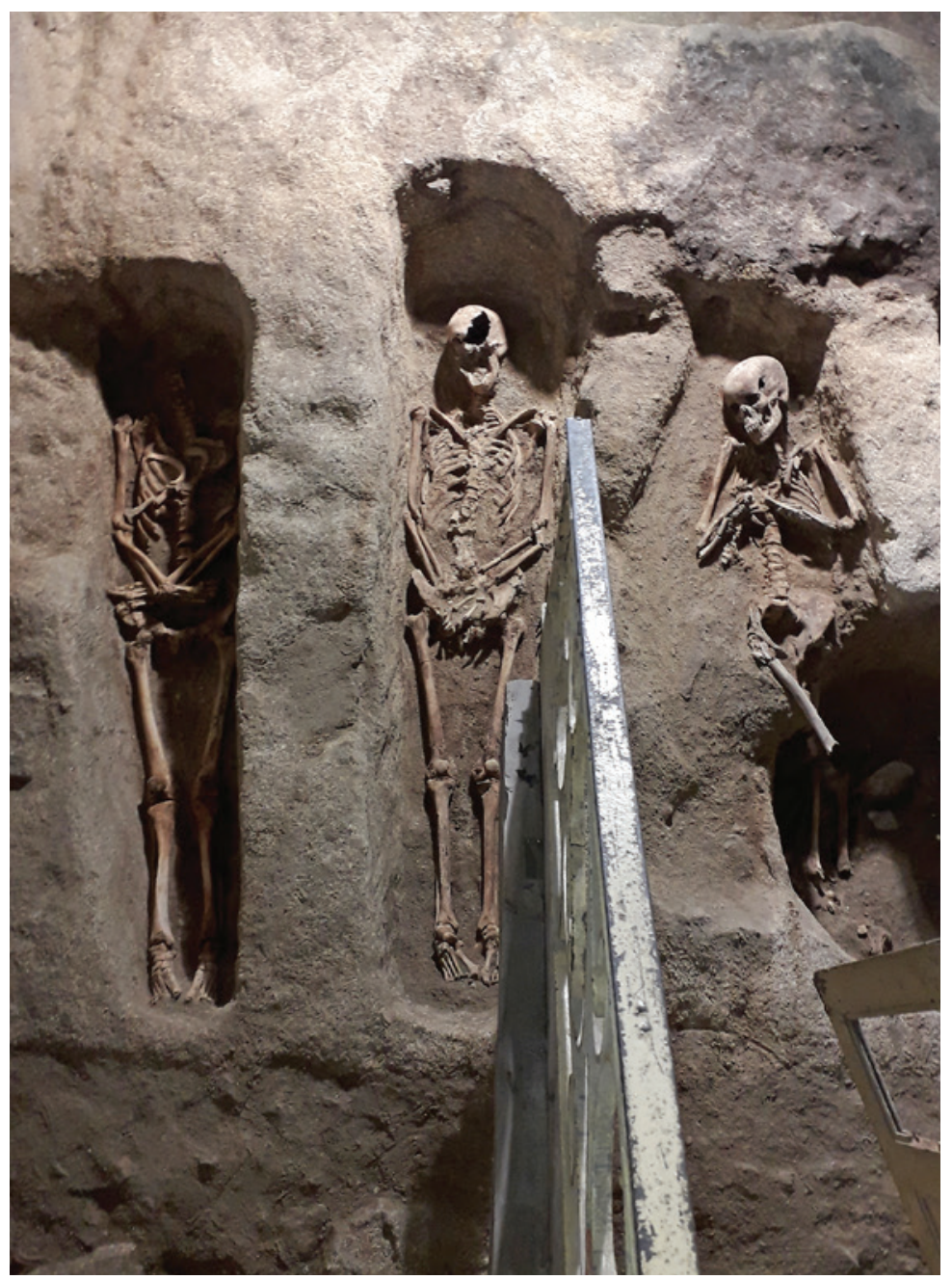

Figura 8 - Sepulturas 14, 17, 15 e, entre as duas últimas, a 16, ainda por escavar. 


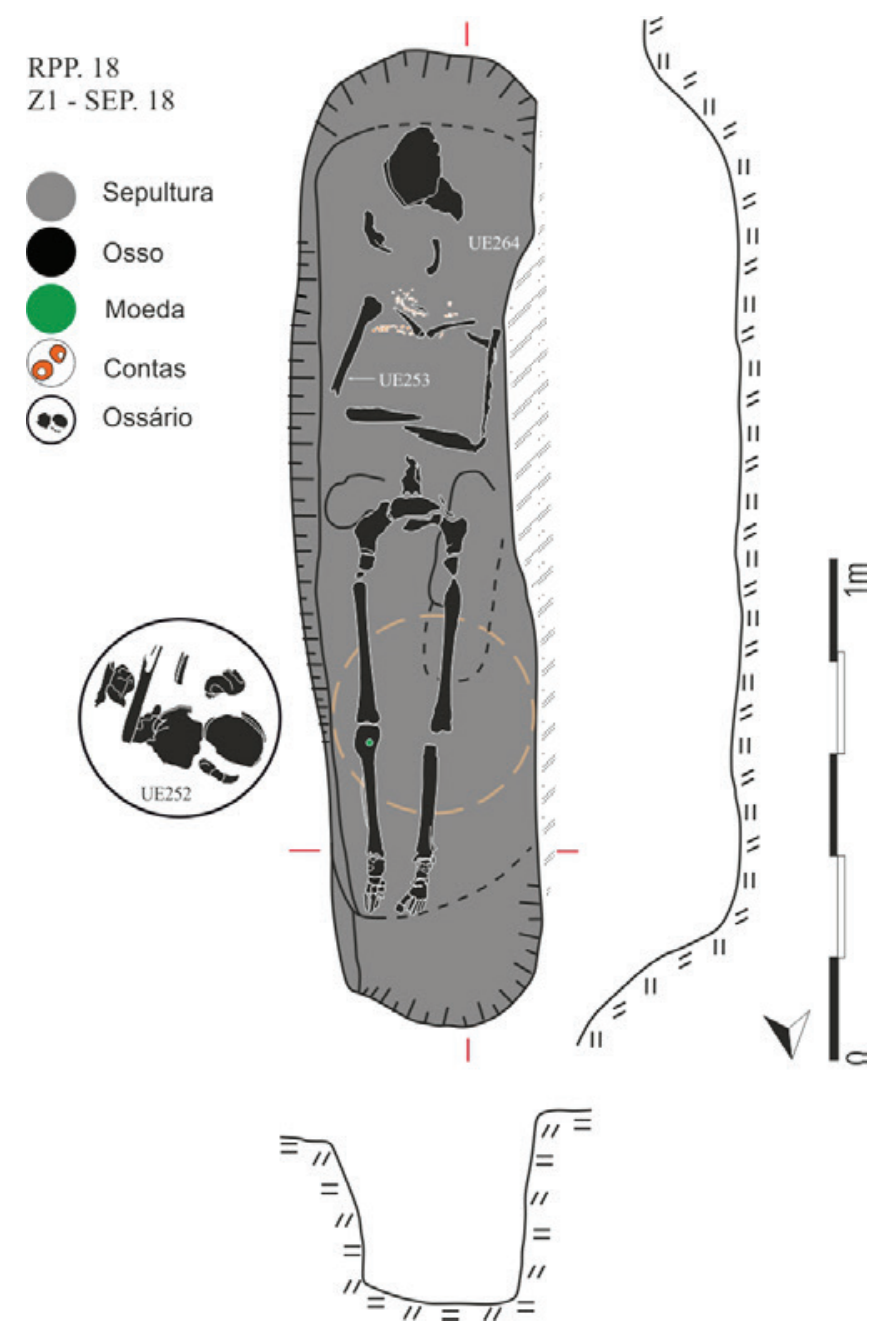

Figura 9 - Sepultura 18, com ossário posterior, ceitil de D. João III e contas em osso e pasta de vidro azul escuro.

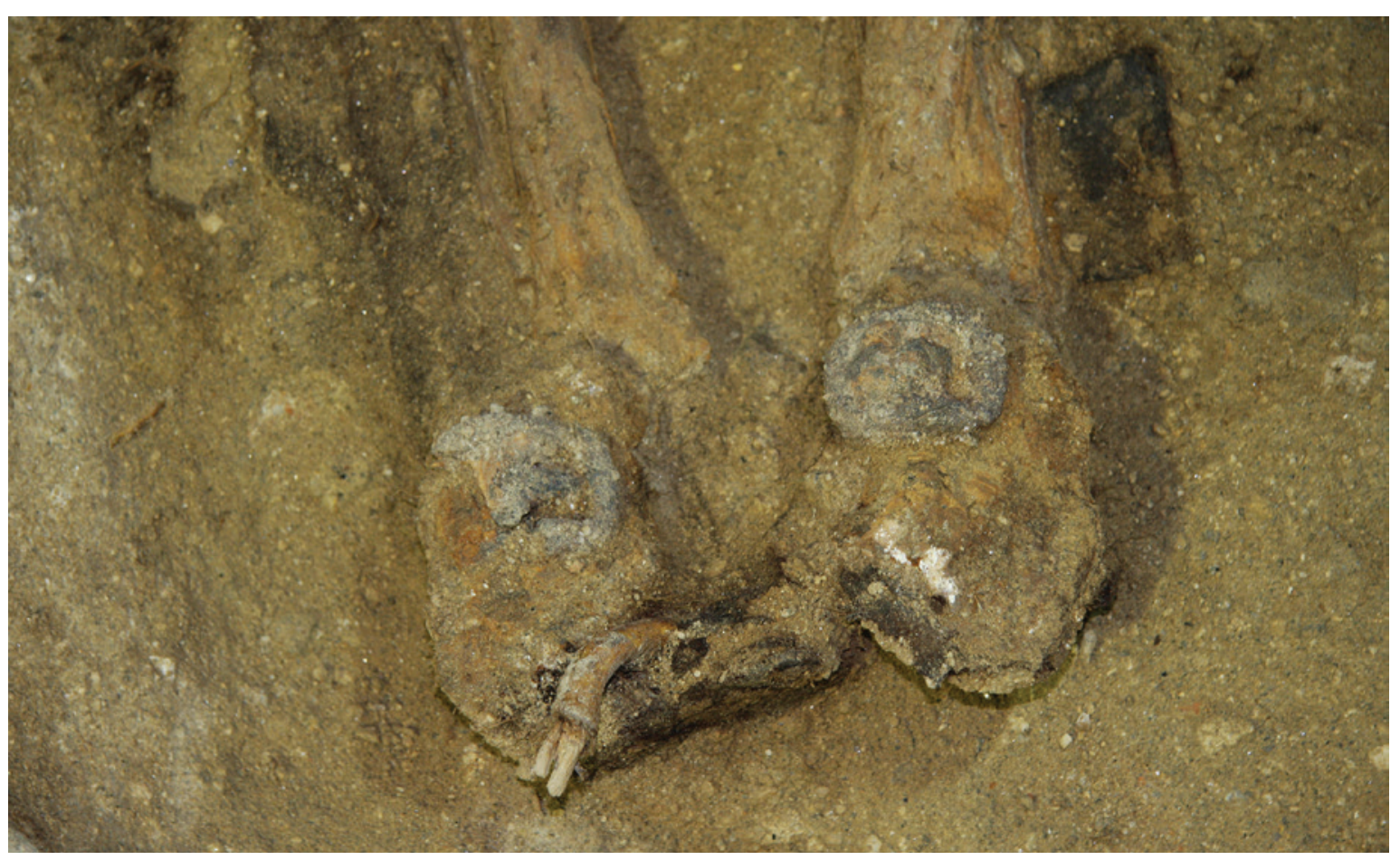

Figura 10 - Sapatos com fivelas, parte da indumentária do indivíduo inumado na sepultura 7. 



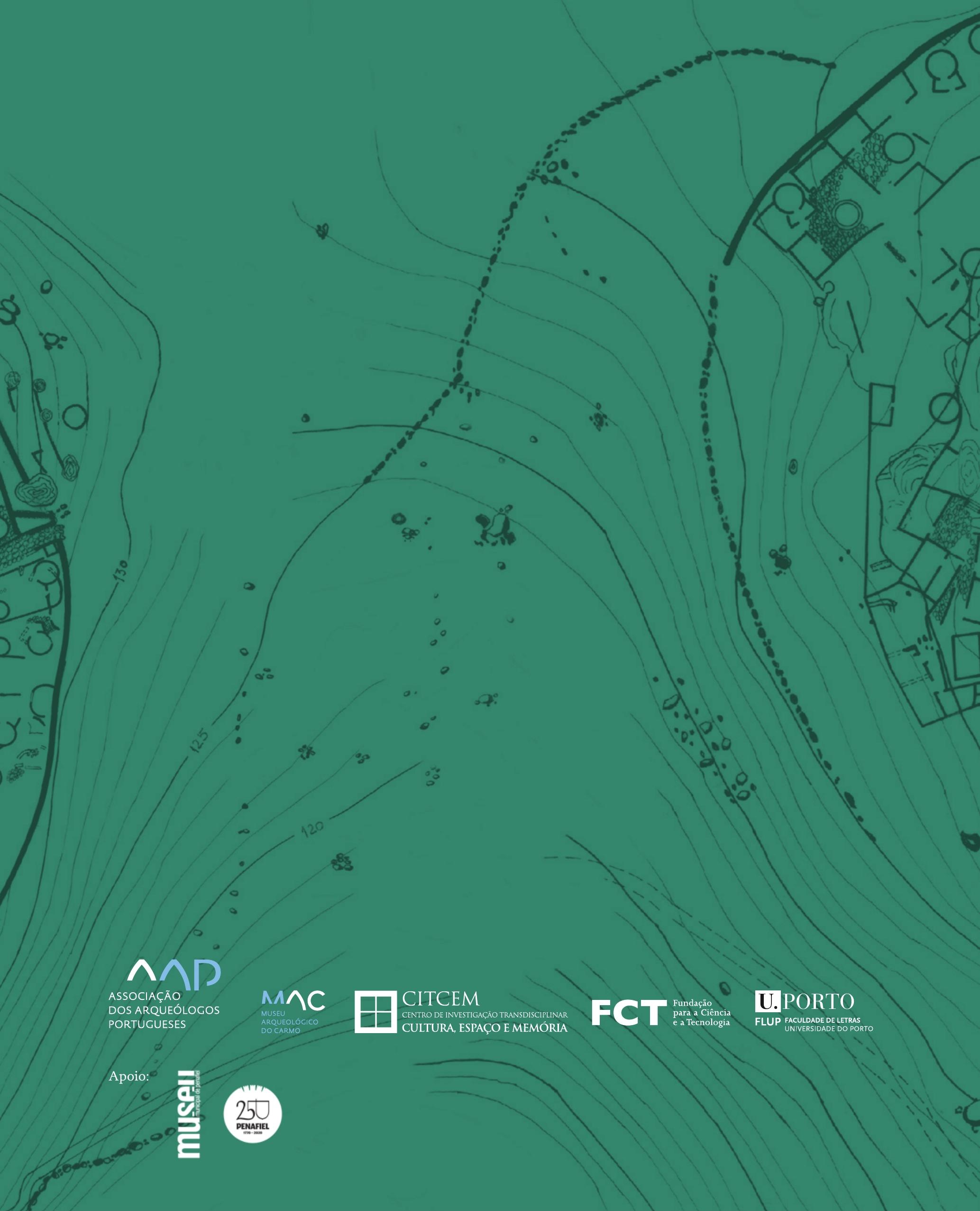

